Review

\title{
Southern Ocean phytoplankton physiology in a changing climate
}

\author{
Katherina Petrou ${ }^{\mathrm{a}, *}$, Sven A. Kranz ${ }^{\mathrm{b}}$, Scarlett Trimborn ${ }^{\mathrm{c}, \mathrm{d}}$, Christel S. Hassler ${ }^{\mathrm{e}}$, \\ Sonia Blanco Ameijeiras ${ }^{\mathrm{e}}$, Olivia Sackett ${ }^{\mathrm{f}}$, Peter J. Ralph ${ }^{\mathrm{g}}$, Andrew T. Davidson ${ }^{\mathrm{h}, \mathrm{i}}$ \\ a School of Life Sciences, University of Technology Sydney, 15 Broadway, Ultimo, New South Wales 2007, Australia \\ ${ }^{b}$ Florida State University, Department of Earth, Ocean and Atmospheric Sciences, Tallahassee, FL 32306, USA \\ ${ }^{c}$ Alfred Wegener Institute, Helmholtz Centre for Polar and Marine Research, Am Handelshafen 12, 27570 Bremerhaven, Germany \\ d University of Bremen, Leobener Straße NW2, 28359 Bremen, Germany \\ e University of Geneva, Earth and Environmental Sciences, Institut F.-A. Forel, Uni Vogt, 66 bvd Carl-Vogt, 1211 Geneva 4, Switzerland \\ ${ }^{\mathrm{f}}$ School of Biological Sciences, Monash University, Melbourne, Victoria, Australia \\ g Plant Functional Biology and Climate Change Cluster, University of Technology Sydney, 15 Broadway, Ultimo, New South Wales 2007, Australia \\ h Department of the Environment, Australian Antarctic Division, 203 Channel Highway, Kingston, Tasmania 7050, Australia \\ ${ }^{\mathrm{i}}$ Antarctic Climate and Ecosystem Cooperative Research Centre (ACECRC), University of Tasmania, Private Bag 80, Hobart, Tasmania 7001, Australia
}

\section{A R T I C L E I N F O}

\section{Article history:}

Received 4 January 2016

Received in revised form 4 May 2016

Accepted 6 May 2016

Available online $\mathrm{xxx}$

\section{Keywords:}

Southern Ocean

Phytoplankton

Marine primary productivity

Climate change

\begin{abstract}
A B S T R A C T
The Southern Ocean (SO) is a major sink for anthropogenic atmospheric carbon dioxide $\left(\mathrm{CO}_{2}\right)$, potentially harbouring even greater potential for additional sequestration of $\mathrm{CO}_{2}$ through enhanced phytoplankton productivity. In the SO, primary productivity is primarily driven by bottom up processes (physical and chemical conditions) which are spatially and temporally heterogeneous. Due to a paucity of trace metals (such as iron) and high variability in light, much of the SO is characterised by an ecological paradox of high macronutrient concentrations yet uncharacteristically low chlorophyll concentrations. It is expected that with increased anthropogenic $\mathrm{CO}_{2}$ emissions and the coincident warming, the major physical and chemical process that govern the SO will alter, influencing the biological capacity and functioning of the ecosystem. This review focuses on the SO primary producers and the bottom up processes that underpin their health and productivity. It looks at the major physico-chemical drivers of change in the SO, and based on current physiological knowledge, explores how these changes will likely manifest in phytoplankton, specifically, what are the physiological changes and floristic shifts that are likely to ensue and how this may translate into changes in the carbon sink capacity, net primary productivity and functionality of the SO.
\end{abstract}

\section{Contents}

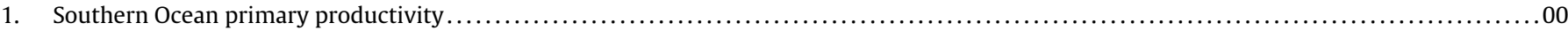

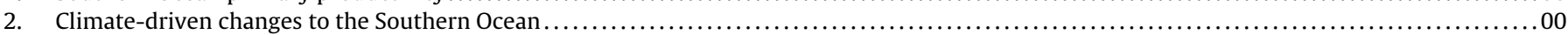

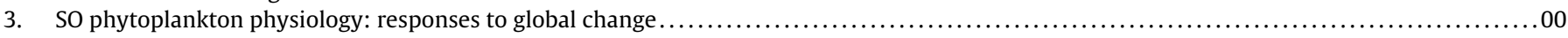

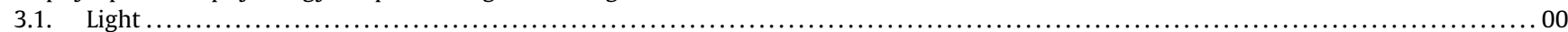

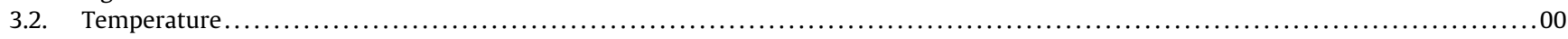

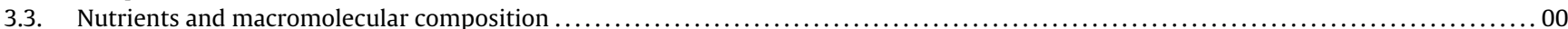

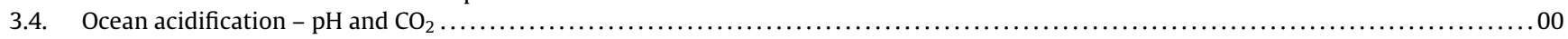

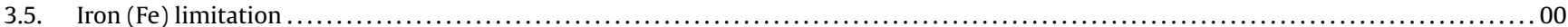

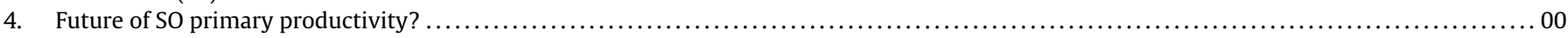

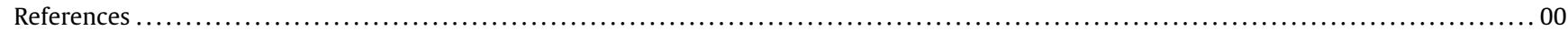

Abbreviations: SO, Southern Ocean; SSIZ, seasonal sea ice zone; POOZ, permanently open ocean zone; MIZ, marginal ice zone; MLD, mixed layer depth; HNLC, high nutrient low chlorophyll; SAM, Summer Annual Mode; ACC, Antarctic Circumpolar Current; PAR, photosynthetically active radiation; UVR, ultra violet radiation; CCM, carbon concentrating mechanism; CA, carbonic anhydrase; PSI, photosystem I; PSII, photosystem II; NPQ non-photochemical quenching; SST, sea surface temperature; OA, ocean acidification; POC, particulate organic matter; NPP, net primary productivity.

* Corresponding author.

E-mail address: Katherina.Petrou@uts.edu.au (K. Petrou). 


\section{Southern Ocean primary productivity}

The Southern Ocean (SO), defined as waters south of the Subtropical Front, is one of the major ocean biomes on the planet, making up $20 \%$ of the global ocean (Boyd, 2002). It is a dynamic marine ecosystem and plays an important role in the regulation of the Earth's climate. The strong easterly flow of the Antarctic Circumpolar Current (ACC) allows for oceanic exchange, thermohaline circulation and global heat exchange, as well as contributing to global $\mathrm{CO}_{2}$ drawdown (Rintoul and Bullister, 1999), where it is estimated to absorb $\sim 20 \mathrm{Gt}$ of atmospheric $\mathrm{CO}_{2}$ annually (Takahashi et al., 2002; Sabine et al., 2004). Phytoplankton are the link that couples atmospheric and oceanic processes. They are a highly diverse group of microscopic photosynthesising protists that inhabit the sunlit surface waters of the ocean and are key to the health and productivity of the marine ecosystem, influencing nutrient cycling, food web dynamics and global biogeochemical cycling (Buesseler, 1998; Garibotti et al., 2003a,b). Global carbon biomass of phytoplankton equates to less than $1 \%$ of the total photoautotrophic biomass on the planet (Bryant, 2003), yet accounts for $40-50 \%$ of global carbon fixation (Field et al., 1998), with more than 100 million tonnes of inorganic carbon fixed by phytoplankton on a daily basis (Behrenfeld et al., 2006). This organic carbon is transferred through the food web, re-released to the atmosphere or sequestered to ocean depths, through a process known as the biological pump. The efficacy of the biological pump is a function of phytoplankton physiology and community structure, which are in turn governed by the physical and chemical conditions of the ocean. Given its pivotal role in atmospheric, oceanic and trophic processes, knowledge of SO phytoplankton photosynthesis and photosynthetic processes are vital to understanding variability in marine primary production under a changing climate.

In the SO, primary production is mediated by a range of physical, chemical and biological factors, namely micronutrients (especially iron) and light, mixed layer depth, sea ice retreat, $\mathrm{CO}_{2}$ concentration, grazing and senescence. The system is also influenced by loss processes such as sinking, aggregation and viral infection. Together these factors divide the SO into distinct provinces (Fig. 1) and generate functional assemblages of microbes that are predictable in space and time (Boyd, 2002; Constable et al., 2014). The principal dichotomy defining these functional assemblages is the presence of sea ice. Approximately $60 \%$ of the SO remains ice-free throughout the year (the permanently open ocean zone, POOZ). Primary productivity in these high nutrient, low chlorophyll (HNLC) waters is commonly co-limited by light and iron availability (Boyd et al., 2007). The deep well-mixed waters carry cells out of their optimal light environment, limiting rates of biomass accumulation (e.g. Nelson and Smith, 1991; Strutton et al., 2000), while iron limitation restricts phytoplankton productivity and favours a relatively stable community of nano- and picoplanktonic phytoplankton (e.g. Ishikawa et al., 2002), however, large, lightly silicified diatoms can also occur (Davidson et al., 2010). There are some exceptions in the POOZ, such as the Antarctic Polar Front (PF), in the lee of islands or where bottom topography enriches surface waters with iron, that are able to sustain larger, often heavily silicified phytoplankton in relatively high concentrations (Sokolov and Rintoul, 2007).

The productivity of the remaining $40 \%$ of the SO ( $\sim 19$ million $\mathrm{km}^{2}$ ) is strongly influenced by seasonal ice cover (Gloerson et al., 1992). The areal extent of the sea ice (Fig. 1) makes it one of the largest biomes on Earth (Massom and Stammerjohn, 2010) and the seasonal sea ice zone (SSIZ) supports 5-30\% of the annual primary production (Legendre et al., 1992; Arrigo et al., 1998, 2010). It provides an environment in which algae thrive, with high concentrations growing on the underside of the sea ice forming a vital source of winter-spring nutrition to higher trophic levels (Arrigo and Thomas, 2004; Massom and Stammerjohn, 2010). In addition, incorporation of algae into and upon the ice effectively provides a "life boat", enabling algal cells to be retained in a maximally sunlit environment over winter (Wright et al., 2010). As summer approaches, increased phytoplankton production, together with dilution of the sea ice brine and the dissolution of carbonate crystals, results in the sea ice region becoming a net sink for $\mathrm{CO}_{2}$ that can contribute approximately $58 \%$ of the net uptake by the SO (Delille et al., 2014).

Melting sea ice releases fresh, buoyant, iron enriched (winter accumulation of aeolian input), water and phytoplankton into the water column, initiating a phytoplankton bloom which retreats southward in the wake of the receding ice edge over the austral summer (Lannuzel et al., 2007; Constable et al., 2014). The meltwater stabilises the water column, shallowing the mixed layer depth (MLD) and entraining cells in a high light, high nutrient environment. The simultaneous release of microalgae (some active and some dormant) into the water column, are said to seed blooms in the marginal ice zone (MIZ) (Mangoni et al., 2009), however, a large proportion of the population sediments rapidly from the photic zone (Wright and van den Enden, 2000; Wright et al., 2010). At its maximum extent in December, the MIZ covers $\sim 6$ million $\mathrm{km}^{2}$, or approximately $39 \%$ of the SSIZ (Fitch and Moore, 2007). The magnitude, extent and timing of SSIZ blooms is profoundly affected by the timing of sea ice disappearance, prevailing wind speed and wave action (Fitch and Moore, 2007; Massom and Stammerjohn, 2010; Constable et al., 2014). As a result, only a relatively small proportion of the entire MIZ (17-24\% in December and February, respectively) actually supports the development of phytoplankton blooms (Fitch and Moore, 2007). Despite this patchiness, MIZ blooms can contribute $25-67 \%$ of all the planktonic production in the SO (Smith and Nelson, 1986). They can extend over thousands of kilometres and can increase the phytoplankton biomass more than two orders of magnitude during November and December, before declining again in January (Smith et al., 2003; Smith and Lancelot, 2004; Moore and Abbott, 2000; Fitch and Moore, 2007). This seasonal cycle is driven by the physical changes associated with ice retreat and its amplitude increases southward, with maximum biomass and productivity in coastal and shelf areas (Smith and Nelson, 1985; Arrigo and van Dijken, 2003,b; Arrigo et al., 2008a,b; Westwood et al., 2010; Wright et al., 2010). The Western Antarctic Peninsula (WAP) has chlorophyll concentrations that can reach up to $50 \mu \mathrm{g} \mathrm{L}^{-1}$ in waters off Palmer Station (Tortell et al., 2014; Goldman et al., 2015; Kranz et al., 2015; Young et al., 2015; PALTER database), while in East Antarctic waters maximum chlorophyll concentrations are commonly more than an order of magnitude less (Wright and van den Enden, 2000; Wright et al., 2010). However, while the magnitude of the blooms may differ, the successional sequence of the phytoplankton in East and West Antarctic waters appear to be similar (e.g. Wright and van den Enden, 2000; Garibotti et al., 2003a,b; Wright et al., 2010).

The SO harbours a prolific and diverse protistan community dominated by diatoms, haptophytes and dinoflagellates, superimposed upon a background of pico- and nanophytoplankton (e.g. Wright et al., 2010; Wolf et al., 2013). The succession of environmental changes imposed on phytoplankton by recession of the sea ice in the SSIZ generates a predictable sequence of events from bloom formation, growth and production, to grazing, senescence and flux, and a predictable succession of phytoplankton functional assemblages and even taxa (e.g. Kang and Fryxell, 1993; Kang et al., 2001; Constable et al., 2014) (Fig. 2). During the winter, the sea ice hosts a diverse and metabolically active algal population dominated by psychrophilic diatoms (Stoecker et al., 2000; Kattner et al., 2004; Meiners et al., 2009; Petrou et al., 2010, 2011c). Satellite derived data, long-term databases and annual research cruises show that the retreat of sea ice initiates a bloom of diatoms in highly stratified waters and shelf areas (Garibotti et al., 2003a, 


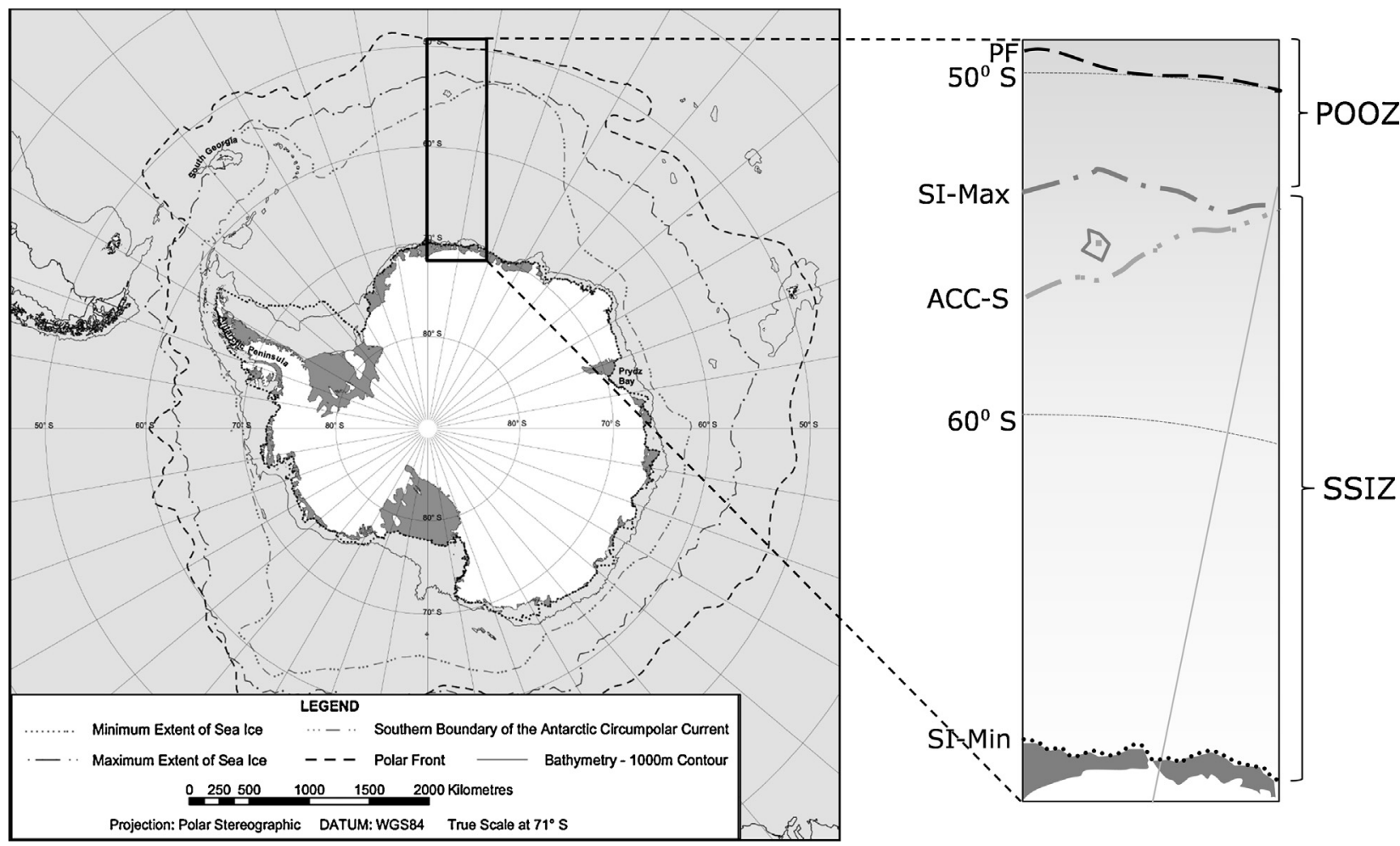

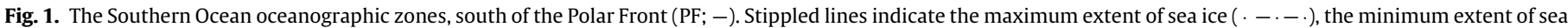

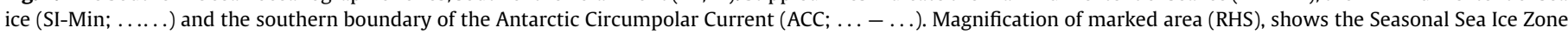

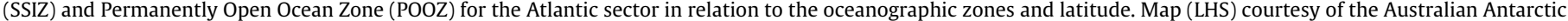
Division. ${ }^{\odot}$ Commonwealth of Australia 2004.

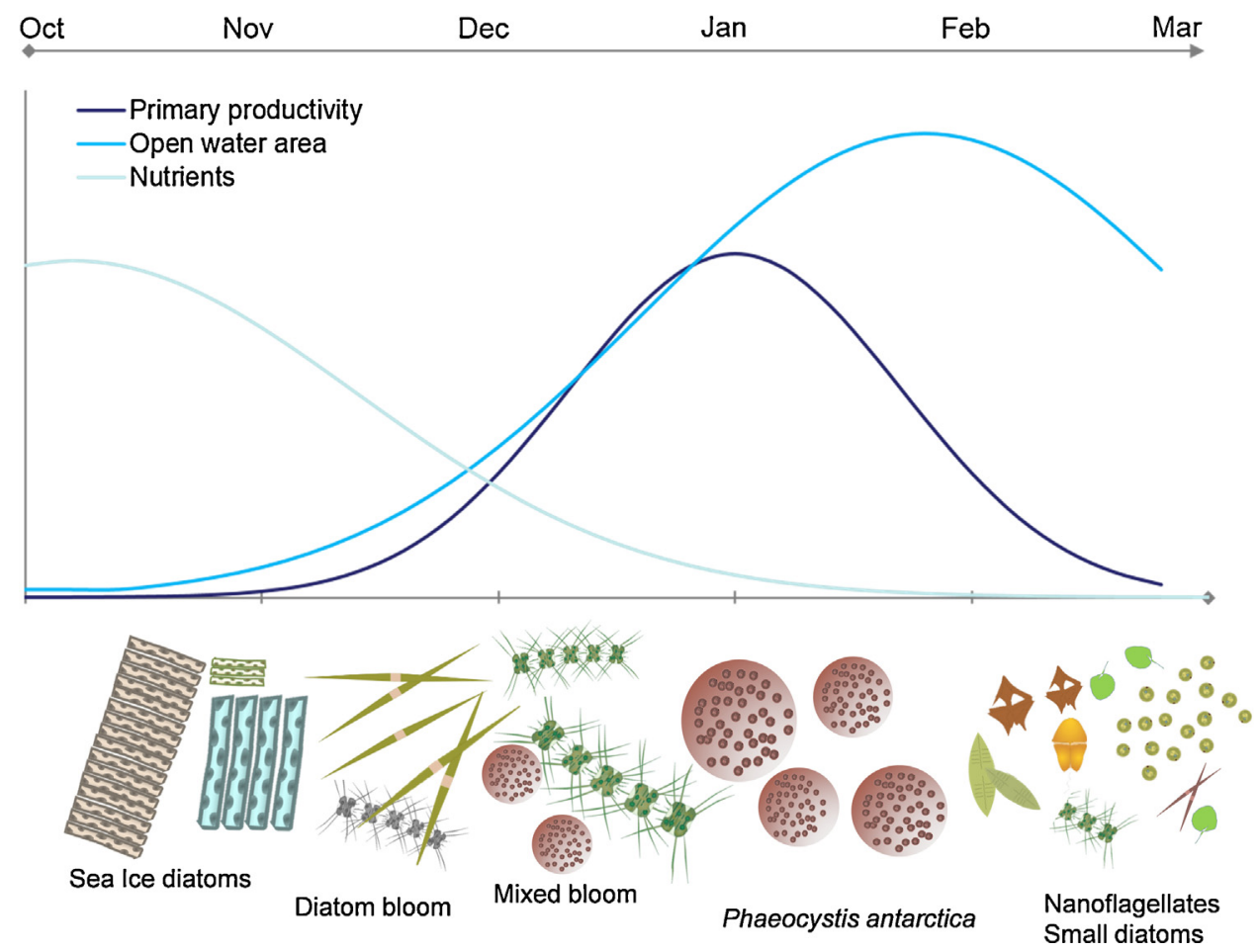

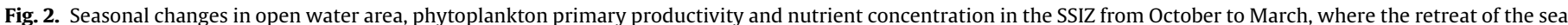

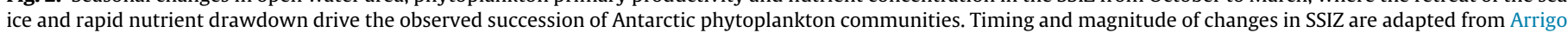
et al. (2008b) and species succession information taken from Kang et al. (2001), Garibotti et al. (2003a,b) and Wright et al. (2010).

2003b; Alvain et al., 2008; Arrigo et al., 2008b). The spring diatom blooms deplete reserves of nutrients such as iron and silicate (e.g. Boyd, 2002) favouring blooms of the colonial, gelatinous Phaeo- cystis antarctica, which are not so heavily grazed (Dennett et al., 2001; Wright et al., 2010). This leads to large expanses dominated by this haptophyte, particularly in the more deeply mixed and iron 
depleted areas. Senescence of this bloom, largely due to aggregation and sinking (DiTullio et al., 2000) leads to a community comprised of autotrophic nanoflagellates, including dinoflagellates, prasinophytes, cryptophytes, chlorophytes, chrysophytes and some diatoms (Fig. 2) (e.g. Peeken, 1997; Kang et al., 2001; Wright et al., 2010; Mills et al., 2012).

In general, due to the different in-water irradiance and nutrient dynamics, Antarctic coastal waters are more productive than the POOZ (Smith and Nelson, 1985; Arrigo et al., 2008a,b; Wright et al., 2010). A spatial study using a mechanistic three-dimensional biogeochemical model of the Ross Sea, found Antarctic shelf waters to be a strong sink for $\mathrm{CO}_{2}$, due to high biological productivity, intense winds, high ventilation rates and extensive winter sea ice cover (Arrigo et al., 2008a). In contrast, a temporal study found substantial inter-annual variability in primary productivity across all regions of the SO between 1997 and 2005, which appeared to be driven in large part by sea ice dynamics (Smith and Comiso, 2008). Given the vast expanse and spatial and temporal variability in primary productivity across the entire SO, models will play an increasingly important role in helping predict future ocean conditions. However, for these models to formulate a complete understanding of SO primary productivity and changes to carbon sequestration, they will need to integrate the physiological complexity of the biota and the spatial dynamics of the annual sea ice cycle.

\section{Climate-driven changes to the Southern Ocean}

Surface waters of the SO are expected to become warmer, fresher and more stratified with shallower MLD, reduced ice thickness, higher $\mathrm{CO}_{2}$ concentrations, less sea ice and stronger westerly winds (Boyd et al., 2008; Constable et al., 2014). Together these spatially heterogeneous changes will differentially affect phytoplankton productivity and carbon sequestration by altering ambient temperature, total irradiance and wavelength structure, nutrient availability and trophodynamics (Bopp et al., 2001; Boyd et al., 2008; Caron and Hutchins, 2013; Lewandowska et al., 2014). The effects of these changes on the distribution, composition and productivity of Antarctic marine microbes are poorly understood and difficult to predict (Marchant et al., 2001; Caron and Hutchins, 2013).

The SO is already experiencing the effects of climate change. Temperatures are increasing, ocean fronts are moving southward and there are region-specific changes in sea ice cover (Constable et al., 2014 and refs therein). Ozone depletion and greenhouse gasses have increased the strength of the Summer Annual Mode (SAM), which in its positive phase contracts the westerly wind belt southwards and increases their velocity. Ironically, these humaninduced changes to the atmosphere have mitigated the southward penetration of global warming around Antarctica (Fyfe et al., 1999; Marshall, 2003; Turner et al., 2009; Swart and Fyfe, 2012). However, the continuing release of greenhouse gasses and the recovery of the ozone hole will inevitably cause future climate-induced warming and ecosystem change in Antarctic waters (Smetacek and Nicol, 2005; Boyd et al., 2008; Constable et al., 2014). Warming temperatures will unavoidably result in a decline in sea ice duration, extent and thickness (Constable et al., 2014 and refs therein). Sea ice plays a vital role in structuring the habitat and regulating the timing of biological production in the SO. It forms an essential feeding zone and breeding platform for higher trophic organisms, influencing recruitment, as well as reproductive and foraging behaviour for many species within the ecosystem and creates appropriate environmental conditions that foster phytoplankton blooms in the MIZ (Fig. 3). Decreased sea ice extent would restrict the productivity in the ice itself, reducing the drawdown of $\mathrm{CO}_{2}$ and compromising the winter-spring nutrition for keystone species in the Antarctic ecosystem such as krill (Massom and Stammerjohn, 2010; Delille et al., 2014). In addition, any reduction in sea ice area in the SO would limit its mediation of MLD, light climate, and micronutrient concentrations by sea ice melt; the very environmental changes that initiate the MIZ bloom and contribute much of the phytoplankton production that fuels the wealth of Antarctica life.

In the Arctic, the thinning and disappearance of sea ice has lengthened the phytoplankton growing period and has reportedly increased the net annual productivity (Arrigo et al., 2012; Bélanger et al., 2013) but this may not occur in Antarctic waters. Increasing temperature is predicted to strengthen stratification and shallow the MLD, reducing the flux of nutrients to surface waters (Bopp et al., 2001; Boyd and Doney, 2002; Boyd et al., 2008; Lewandowska et al., 2014). In the absence of enrichment of surface waters with iron from the melting ice, nutrient limitation is likely to constrain phytoplankton productivity (e.g. Boyd, 2002). Furthermore, nutrient limitation would foster phytoplankton communities typical of the POOZ, which are dominated by small flagellates (Ishikawa et al., 2002), grazed by microheterotrophs, which sink slowly and are likely to be remineralised in near-surface waters (Lewandowska et al., 2014), reducing carbon export. Conversely, Doney (2006) argued that increased stratification of the SO may increase phytoplankton production by reducing the deep mixing that often constrains their productivity. The net effect of these opposing processes in an increasingly ice-free SO is uncertain.

More than $90 \%$ of the extra heat energy from greenhouse warming is absorbed by the ocean (Stocker, 2015), raising the temperature of the ocean, particularly at high latitudes (Levitus et al., 2005; Domingues et al., 2008). Rising temperature could directly affect phytoplankton productivity by altering metabolic rates (Boyd et al., 2013; Lewandowska et al., 2014), as ambient water temperatures in the SO are commonly sub-optimal for the growth of Antarctic phytoplankton (Moisan et al., 2002). Thus, increasing sea surface temperatures are expected to increase photosynthesis and cause floristic shifts towards warm-water species, while restricting cold-water species' ranges and reducing their present distribution and potentially the biodiversity of these cold water communities (Hays et al., 2005). Studies of Antarctic phytoplankton indicate that a rise in temperature alone causes only a modest increase in their growth rate (e.g. Rose et al., 2009; Boyd et al., 2013,2015 ) and this increase is often overcompensated by the negative effects of increased temperature on abiotic and biotic stressors such as nutrient limitation and grazing (Caron and Hutchins, 2013; Lewandowska et al., 2014).

The increased velocity of the westerly winds as a result of the increase in positive SAM can enhance upwelling that enriches surface waters with nutrients. These nutrient-rich waters are driven northward by Ekman drift and promote productivity by diatoms south of the Polar Front (Lovenduski and Gruber, 2005). This agrees with studies using satellite observations to drive models of phytoplankton composition and abundance at synoptic spatial scales. These show that the increasingly positive SAM index correlated with an increase in diatom abundance (Alvain et al. 2013; Rousseaux and Gregg, 2015). Thus, SAM-induced upwelling of nutrient-rich waters may offset the effects of nutrient limitation due to the warming-induced increased stratification. Yet the increasing winds due to SAM have also increased eddy kinetic energy and the poleward movement of these eddies may mitigate the Ekman transport of nutrient rich water to the north (Lovenduski and Gruber, 2005). The net result of these opposing forces on phytoplankton in the SO is unclear, but the combined effect of increased upwelling and stratification may enhance phytoplankton production in waters between the Polar Front and SSIZ (Lovenduski and Gruber, 2005; Doney, 2006).

The concentration of hydrogen ions (protons) in the ocean has increased approximately $30 \%$ since the start of the industrial revo- 


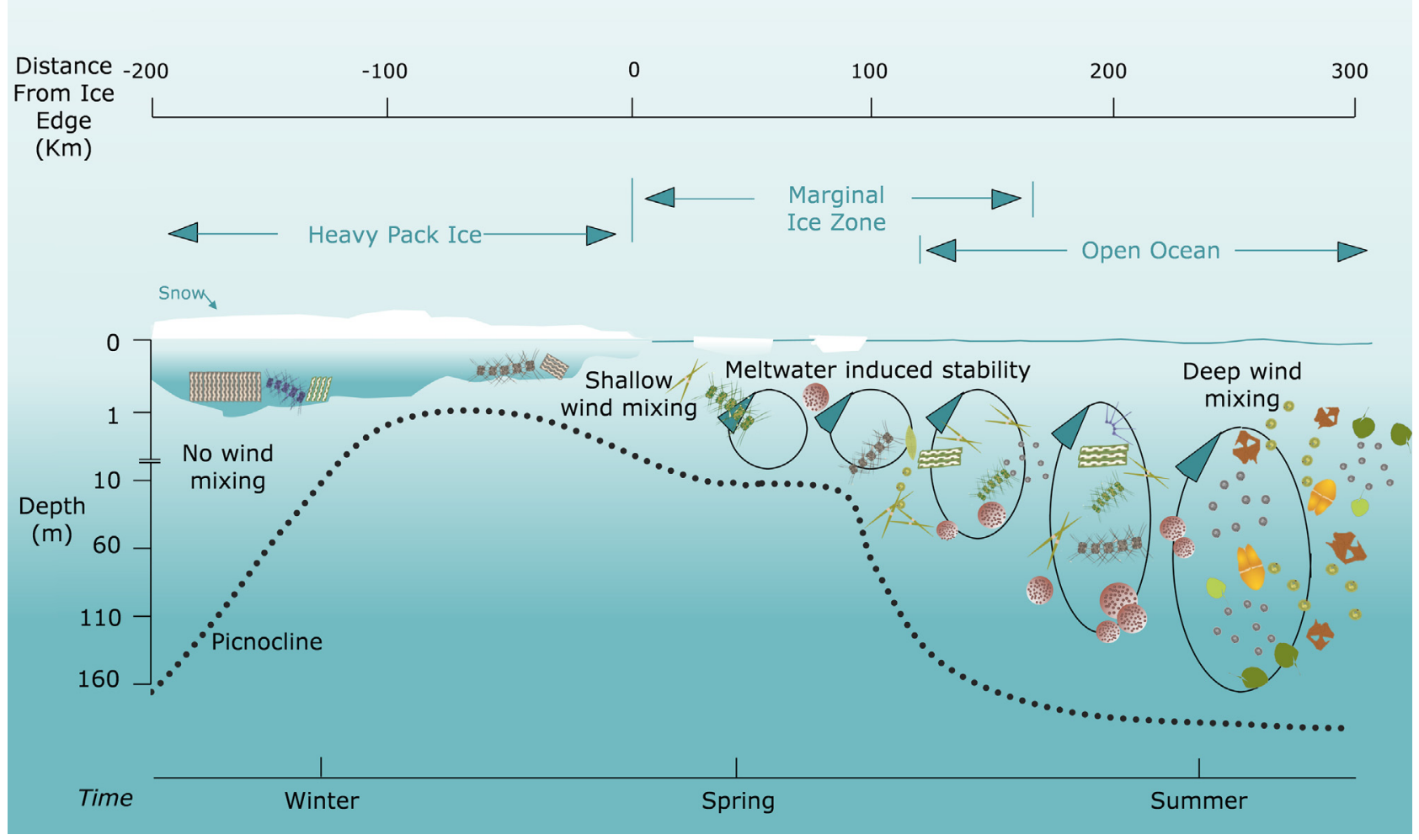

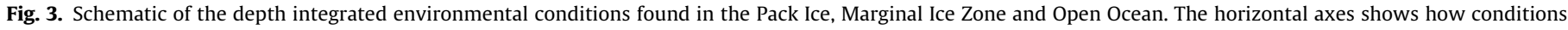
change spatially (top X-axis) and temporally (bottom X-axis) in the Antarctic marine ecosystem and its influence on phytoplankton communities.

lution and is predicted to increase by more than $100 \%$ by the end of this century (RCP 8.5; IPCC et al., 2014). This is particularly concerning for the SO ecosystem, as the cold, high latitude waters of the SO are recognised as the world's largest $\mathrm{CO}_{2}$ sink (Sabine et al., 2004). Responses of marine microbes to elevated $\mathrm{pCO}_{2}$ differ among studies. A number of studies conducted in polar waters indicate that moderate enhancement of $\mathrm{CO}_{2}$ concentration promotes phytoplankton production and fosters the growth of large diatoms (Engel et al., 2008; Tortell et al., 2008a; Feng et al., 2010), while others find it promotes the growth of pico- and nanoplankton (Hare et al., 2007; Brussaard et al., 2013). Overall, differences in competitive fitness among phytoplankton functional groups indicate that exposure to elevated $\mathrm{pCO}_{2}$ could alter the phytoplankton community in coming decades (Dutkiewicz et al., 2015). Responses by natural coastal communities of Antarctic marine microbes within and among seasons suggest that moderate increases in $\mathrm{CO}_{2}$ concentrations may enhance phytoplankton productivity and growth, but by the end of this century $\mathrm{CO}_{2}$ concentrations may have risen sufficiently that they could alter the species composition, reduce rates of biomass accumulation and enhance the relative abundance of small phytoplankton taxa (Davidson et al., 2016).

The complex interactions and multiple feedback mechanisms involved in biogeochemical and biological processes, makes characterising an ecosystem and predicting its response to environmental change extremely challenging. Commonly, manipulative studies expose individual taxa to single stressors, while in nature, phytoplankton are simultaneously exposed to a range of climateinduced changes in their environment and the responses are potentially mediated by interactions within and among trophic levels (Boyd, 2013). The complexity of performing experiments that capture all the physical, chemical and biological changes encompassed above is bewildering to contemplate. Instead, Boyd et al. (2015) identified the key climate-induced stressors for a subantarctic location and exposed a diatom from this region to combinations of these stressors to simulate different climate scenarios. Results showed that different combinations of stressors elicited markedly different response. In general, simultaneous exposure to all the predicted stressors was beneficial to growth and net productivity (biomass) (Boyd et al., 2015). Specifically, when nutrient-replete, diatom growth rates doubled under future (2100) conditions, primarily as a result of Fe enrichment and warming (Boyd et al., 2015). Such composite studies, while complex and logistically demanding to perform, are necessary to help predict future changes in productivity and carbon flux in the SO.

\section{SO phytoplankton physiology: responses to global change}

Characterising phytoplankton physiological responses to environment change is complex, as measurements of primary productivity require an understanding of multiple physiological processes including light harvesting capacity, electron transport, carbon fixation, nutrient requirement and utilisation, and the sensitivity of each of these processes to environmental perturbation. Phytoplankton diversity adds an additional layer of complexity since species-specific responses can differ substantially in their magnitude, speed and direction.

Over geological time, SO phytoplankton diversification has been driven by extreme variation in physico-chemical conditions. Large variations in light, temperature, nutrients $\left(\mathrm{N}, \mathrm{P}, \mathrm{Si}, \mathrm{Fe}\right.$ and $\left.\mathrm{CO}_{2}\right)$ and salinity occur spatially (from the sea ice to the open ocean) and seasonally (Fig. 3). In the sea ice, phytoplankton are incorporated into the ice matrix, and are exposed to freezing, hypersaline conditions within the brine channels (Thomas and Dieckmann, 2002) as well as low light or complete darkness for several months of the year. In the MIZ, productivity is generally high, due to the stable, nutrient rich, sun-drenched conditions and lower salinity from the melt- 
ing ice (Fig. 3). This contrast strongly with the deep, well-mixed, iron-poor waters of the POOZ (Fig. 3).

Projected physical and chemical changes to the future ocean are relatively well characterised, and while the biological responses to these changes are less clearly defined, our understanding of bottom up influences on marine productivity is much greater than that of top down affects (Constable et al., 2014). Indeed, while there are still many gaps to fill, the most detailed knowledge on changes to ocean productivity come from phytoplankton studies. Much less is known about how grazing and higher trophic dynamics (top down processes) will be affected by climate change and in turn how these altered physiologies and ecologies will influence the lower trophic processes and ultimately the net productivity of the ecosystem. In this section we present the current state of knowledge on the physiological responses of SO phytoplankton to the changes in ocean physico-chemical conditions (light, temperature, macronutrients, $\mathrm{pH}$ and Fe availability) projected under future climate.

\subsection{Light}

Light underpins all primary productivity, and as such, any environmental stress (from alterations in light and nutrient availability, or sudden changes in temperature or salinity) experienced by phytoplankton can manifest in the photophysiology of the organism. Thus knowledge of primary productivity and how it may change in the future requires an understanding of the balance between incoming excitation energy and outgoing demand for electrons used in carbon fixation (Critchley, 1997) and other photophysiological processes, such as photoacclimation.

Photoacclimation is a complex light response that results from changes in cellular activity and adjustment of physiological properties to balance photosynthetic electron transport with metabolic demands, such as nutrient uptake (Falkowski and La Roche, 1991). Strategies of photoacclimation vary from one species to another, having a strong influence on species distribution and abundance through specialised niche differentiation. Differences in photoacclimation strategy are due to the heterogeneity in photosynthetic structure and accessory pigment composition between species, influencing the rate and quantity of photons received by the photosystem (Wilhelm, 1990). Some species acclimate by changing the size of the light harvesting antenna of the individual reaction centre, while others increase the total number of reaction centres, keeping antenna size constant (Falkowski and LaRoche, 1991; Moore et al., 2006). As with temperate diatoms (Ruban et al., 2004; Dimier et al., 2007; Lavaud et al., 2007), SO- and sea ice diatoms are highly plastic to fluctuations in light with a strong dependence on rapid and reversible xanthophyll cycling (Moisan et al., 1998; Moisan and Mitchell, 1999; Kropuenske et al., 2009; Petrou et al., 2011a,c), however, not all species utilise the same strategies, nor have the same level of physiological plasticity (Kropuenske et al., 2009; Mills et al., 2010; Petrou et al., 2011a). This physiological variability results in a wide range of light utilisation efficiency and photoprotective capacities from one phytoplankton species to another, making it important to investigate species-specific photosynthetic activity to understand what drives community composition and ultimately primary productivity.

There have been relatively few studies into the photoacclimation and photoprotection in SO phytoplankton species. At the community level, it has been shown that SO phytoplankton under iron-limitation and high light stress induce high nonphotochemical quenching (NPQ), with a strong dependence on xanthophyll cycling (Petrou et al., 2011b). Similarly, diatom dominated sea ice algal communities are highly plastic (Lizotte and Sullivan, 1991, 1992; Robinson et al., 1997; Petrou et al., 2011c), with rapid induction of NPQ under increased irradiance (Petrou et al., 2011c) and a high intrinsic resistance to photoinhibition
(Petrou et al., 2010). Although they only possess modest photosynthetic protein repair rates, possibly as a result of low temperatures, by rapidly activating xanthophyll cycling, their repair rates are sufficient to keep pace with rates of photoinactivation at irradiances up to $200 \mu$ mol photons $\mathrm{m}^{2} \mathrm{~s}^{-1}$, which is more than ten times in situ light levels (Petrou et al., 2010).

Antarctic species successions and distribution have been investigated previously (Lizotte, 2001; Kopczynska et al., 2007; Almandoz et al., 2008; Beans et al., 2008), with some studies correlating observed distribution with physical and chemical oceanic parameters (Almandoz et al., 2008; Beans et al., 2008). Only a few however, have linked a species physiology and photosynthetic plasticity to its observed distribution and abundance (Kropuenske et al., 2009, 2010; Petrou et al., 2011a; Petrou and Ralph, 2011). Comparison of the photoacclimation strategies of $F$. cylindrus and $P$. antarctica provides an excellent example of how the photoprotective capacity of these two important SO species can be linked with their ecological niche occupancy. F. cylindrus has been shown to utilise rapid and dynamic NPQ under a range of environmental conditions (Mock and Hoch, 2005; Kropuenske et al., 2009, 2010; Petrou et al., 2011a, 2012; Petrou and Ralph, 2012), balancing growth with light acquisition through the modulation of their carotenoid pigments (Petrou et al., 2011a, 2012; Petrou and Ralph, 2012). This species is highly resilient to changes in irradiance, possessing a large chlorophyll a specific optical cross sectional area (useful in low light), yet able to keep excitation pressure low under high light by rapid induction of xanthophylldriven NPQ and regulation of the functional cross sectional area of PSII $\left(\sigma_{\text {PSII }}\right)$ (Kropuenske et al., 2010; Petrou et al., 2011a, 2012; Petrou and Ralph, 2012). This plasticity is not common to all SO diatoms, instead other species exposed to the same stressors, have shown to be less plastic to changes in light, exhibiting limited NPQ capacity and no dynamic control over excitation pressure (Petrou et al., 2011a, 2014), highlighting how photoacclimation strategy may be an important determinant of the success of $F$. cylindrus in polar marine environments (Kang and Fryxell, 1992; Lizotte, 2001; Kopczynska et al., 2007). As with F. cylindrus, the photoacclimation strategy of the prymnesiophyte Phaeocystis antarctica provides us with some insight into the success of this species, including its fast photoacclimation capabilities (Moisan et al., 1998; Kropuenske et al., 2009, 2010) and high investment into carotenoid synthesis under Fe limitation (van Leeuwe and Stefels, 2007). While it appears that these two species utilise similar strategies, studies directly comparing P. antarctica with F. cylindrus found that the former was able to acclimate to changes in irradiance much faster than the diatom, but was much slower to induce NPQ, resulting in more photoinhibitory quenching (Kropuenske et al., 2009; Mills et al., 2010) and a high dependence on photosynthetic protein repair processes (Kropuenske et al., 2009, 2010). Linking their photosynthetic strategies with niche occupancy, the high photoprotective capacity, low susceptibility to photoinhibition and slower photoacclimation rates of F. cylindrus (Kropuenske et al., 2009, 2010; Petrou et al., 2011a), are well suited to the uniform growth conditions of the shallow mixed layer and sea ice, whereas the rapid photoacclimation capacity of $P$. antarctica are consistent with growth in deeply mixed water, where photosynthesis can be maximised during exposure in the sunlit surface waters and any photoinhibition incurred at the surface has time to repair when at depth (Kropuenske et al., 2009, 2010).

The extent to which ocean shoaling (reduced MLD) will influence SO primary productivity is dependent on the photophysiological strategy each organism employs. The predicted reduction in MLD means an increase in the integrated daily irradiance delivered to phytoplankton in the surface waters (Marinov et al., 2010). This trapping of phytoplankton in surface waters exposes them to higher irradiances of photosynthetic active radiation (PAR) and 
damaging, short wavelength ultraviolet radiation (UVR) (Marinov et al., 2010; Caron and Hutchins, 2013 and refs therein). High light and UVR are responsible for photoinhibition and cellular photodamage that can reduce rates of photosynthesis, growth and survival by phytoplankton (Davidson, 2006). Despite the recovery of the ozone layer, the effects of UVR exposure on SO phytoplankton as a result of ocean shoaling are likely to exceed that of previous ozone depletion (Williamson and Zagarese, 2003). However, this physiological stress may be countered by ocean warming, which has been shown to accelerate protein synthesis (Boyd et al., 2015) or similarly, increased Fe bioavailability, which could enhance photosynthesis and quench reactive oxygen species. It is the interplay of different environmental conditions and the physiological responses they invoke, which makes predicting changes to primary productivity challenging. To increase knowledge of the generality of these responses, future research should focus on conducting photophysiological studies with an increased number of species. By comparing the responses of dominant species to environmental stressors, a more complete picture of ecosystem function in relation to species dominance and successions can be obtained. Furthermore, through the use of multi-species competition studies, a better understanding of potential community shifts and the implication for trophic dynamics and carbon cycling at a large scale can be obtained.

\subsection{Temperature}

Temperature has recently been shown to be one of the strongest predictors of future SO diatom primary productivity (Boyd et al., 2015). However, the effect of warming on SO phytoplankton is complex and impossible to predict in isolation of other changing physico-chemical conditions. It is known that warming influences cellular processes such as growth, cell size, carbon and chlorophyll content as well as nutrient requirement in phytoplankton, however, in conjunction with other stressors, such as those that are likely to eventuate in a warmer world (nutrient availability, lowered $\mathrm{pH}$ and increased UVR stress), these responses could easily be steered in alternate directions.

Surface ocean temperatures control the distribution and abundance of phytoplankton in both space and time. Changes in the microbial community are difficult to quantify against a high background of temporal and spatial variability, but evidence indicates that dinoflagellate (Hallegraeff, 2010; McLeod et al., 2012) and Emiliania huxleyi (Cubillos et al., 2007) distributions are migrating poleward. Similarly, increased precipitation and glacial melt from warmer temperatures reportedly favours dominance of cryptophytes over diatoms in Antarctic coastal waters (Moline and Prézelin, 1996; Moline et al., 2004). In addition, the timing, duration and magnitude of phytoplankton blooms is defined by the impact of temperature on the physical environment (e.g. MLD, light, nutrients) but the nature and magnitude of this effect differs among taxa (Sommer and Lengfellner, 2008; Sommer and Lewandowska, 2011). Temperature also affects the timing of phytoplankton blooms by triggering the formation and germination of phytoplankton resting stages (McQuoid and Hobson, 1995). Such changes could result in a temporal mismatch between phytoplankton and higher trophic levels with ramifications for trophodynamics, ecosystem productivity and carbon sequestration in the SO (e.g. Ji et al., 2010).

Antarctic phytoplankton species are well adapted to sub-zero temperatures (Morgan-Kiss et al., 2006), having evolved cryoprotectants (Raymond and Knight, 2003) and anti-freeze proteins (Janech et al., 2006). In general, they show higher growth rates and physiological activity than would be expected (Feller and Gerday, 2003; Morgan-Kiss et al., 2006; Young et al., 2015), which may be a form of cold adaptation, where the cell is able to overcome the slow enzymatic rates usually enforced by cold temperatures (Feller and Gerday, 2003; Morgan-Kiss et al., 2006).

Temperature response functions in computational models allow for reasonably accurate productivity measurements to be made based on satellite chlorophyll and sea surface temperature (SST) measurements (Behrenfeld and Falkowski, 1997). This phenomenon can be explained at the biochemical level, since higher temperatures can increase enzymatic turnover rates (and thus productivity) through increasing the activity of thermally sensitive enzymes (see Wagner et al., 2016)-at least until a maximum rate is reached. This behaviour is defined by the temperature coefficient $\mathrm{Q}_{10}$, which describes a rate change per change of $10^{\circ} \mathrm{C}$ in temperature. An average value of $2-3$ for the $Q_{10}$ of the carboxylating enzyme ribulose-1,5-bisphosphate carboxylase/oxygenase (RubisCO) has been measured in phytoplankton in general and recently verified for SO species (Descolas-Gros and de Billy, 1987; Devos et al., 1998; Sage, 2002; Young et al., 2015). Using this coefficient, if SST of the SO were to rise by $6^{\circ} \mathrm{C}$, it would result in an approximate doubling of physiological activity (growth). However, while higher temperatures can have positive effects on metabolism, species have temperature maxima, beyond which a sharp drop in metabolic efficiency occurs (Boyd et al., 2013). In one study, a temperature increase of $3{ }^{\circ} \mathrm{Cleads}$ to a $25 \%$ increase in growth by a polar diatom, yet further increases in temperature resulted in a rapid decline (Boyd et al., 2013), clearly defining a growth rate thermal maximum.

Increased temperature can alter the balance between the rates of phytoplankton growth and grazing mortality, where the growth and grazing rates of microzooplankton increase more rapidly with temperature than growth of their phytoplanktonic prey (Rose and Caron, 2007; Chen et al., 2012; Caron and Hutchins, 2013). In addition, increases in ocean temperature coincide with a decline in the size of diatom frustules (Falkowski and Oliver, 2007) making them too small to be efficiently captured by krill and favouring their consumption by microheterotrophs such as ciliates (Boyd et al., 1984; Kawaguchi et al., 1999; Caron and Hutchins, 2013 and refs therein). The resultant shift in the SO trophodynamics toward grazing by microzooplankton would reduce the transfer of phytoplankton productivity to higher trophic levels, again favouring the respiration of carbon substrates in surface waters (Wohlers et al., 2006). Furthermore, the resulting decline in the efficiency of the biological pump would have a positive feedback on global climate change. However, grazing and recycling of material in surface waters by the microbial loop may also limit the hypothesised stripping of iron from the upper water column by krill grazing (Wright et al., 2010) allowing the persistence of this vital nutrient to support recycled production.

As one of the strongest predictors of SO diatom productivity (Boyd et al., 2015), understanding the physiological and biochemical responses of key phytoplankton species and mixed communities to temperature is a key priority. However, as discussed in Wagner et al. (2016, this issue), one of the major challenges remaining is to find that key functional trait or traits that provide an invariable temperature-dependent fingerprint.

\subsection{Nutrients and macromolecular composition}

The SO exhibits strong heterogeneity in the distribution and concentration of nutrients. While the SO has some of the highest macronutrients $(\mathrm{N}, \mathrm{P}, \mathrm{Si}$ ) concentrations of any marine province across the globe, $\mathrm{Si}$ and Fe are spatially and temporally variable (Martin, 1990; Coale et al., 2003, 2004; Hiscock et al., 2003; De Baar et al., 2005; Maldonado et al., 2005). This irregularity in nutrient availability greatly influences the spatial dynamics of biological communities and more specifically, the regulation of marine primary production (Hiscock et al., 2003). In phytoplankton, variations in nutrient ratios (elemental stoichiometry) will reflect their under- 
lying allocation of energy into major molecules (RNA, cellulose, lipids, proteins etc) and are closely associated with key traits such as growth rate, and size (Klausmeier et al., 2008; Finkel et al., 2009). Therefore, alterations in elemental ratios can have large effects on rates and efficiencies of energy transfer and elemental cycling in the ocean. Furthermore, through their influence on cell metabolism, nutrient dynamics can alter competitive advantages and thus species dominance and community structure (Klausmeier et al., 2008).

The effect of nutrients on phytoplankton communities extends beyond changes in carbon productivity, as changes in nutrient availability, especially Fe, also influence cellular metabolism, which can lead to substantial shifts in carbon partitioning between macromolecular (proteins, lipid and carbohydrates) stores (Milligan and Harrison, 2000; Van Oijen et al., 2004). Phytoplankton have been shown to alter their macromolecular composition to compensate for reduced RubisCO activity, energy storage and capture of transient nutrient pulses (Armbrust, 2009; Marchetti et al., 2009; Sackett et al., 2013, 2015; Young et al., 2015). Changes in the production of macromolecules by phytoplankton are fundamental to the health and functioning of the marine ecosystem, since the nutritional quality of the phytoplankton affects the efficiency of trophic energy transfer (Hessen et al., 2004). The cellular energy partitioning and macromolecular composition (lipids: proteins: carbohydrates) will determine the nutritional value of the phytoplankton and ultimately, through trophic transfer, the productivity of the ecosystem. Under sea ice conditions (sub-zero temperature, low light and high salinity), microalgae preferentially produce lipid macromolecules for energy storage (Mock and Kroon 2002; Sackett et al., 2013). Lipids are the most energy-rich macromolecules, with approximately double the caloric value of proteins and carbohydrates (Whyte, 1987). Organisms such as juvenile krill depend on these rich sources of lipids for growth and productivity, particularly during the long, winter months (Falk-Petersen et al., 1998; Mock and Kroon, 2002; Lee et al., 2008). However, with predicted reductions in the duration, extent and thickness of sea ice expected with future warming, the physico-chemical conditions that currently drive this large allocation of energy into lipids stores, may alter, causing a shift in cellular resource allocation. A recent study conducted in the naturally Fe-rich waters near the Kerguelen Islands revealed that under high Fe availability, the dominant diatom species Fragillariopsis kerguelensis favoured the production of carbohydrate over lipid or protein stores (Sackett et al., 2014). This was in contrast to the less abundant diatom Pseudo-nitzschia subcurvata, which exhibited a more subtle response, whereby carbon partitioning remained relatively independent of iron availability (Sackett et al., 2014). Plasticity in macromolecular composition may be advantageous to $F$. kerguelensis by allowing the species to switch from producing one type of molecule to another, depending on resource availability.

Phytoplankton are intimately involved in a number of biological feedbacks including the regulation of nutrient stoichiometry in the global ocean (Falkowski et al., 1998). Their influence over these elemental ratios is due in large part to the proportion of sinking cells that are broken down (re-mineralised) releasing their nutrients into the water. As a result, the nutrient ratio of the ocean often reflects the average nutrient ratio (i.e. the elemental stoichiometry) of the entire phytoplankton community (Arrigo, 2005). Given that each species can have a different stoichiometry, any shifts in community composition in response to climate change, could alter the nutrient budget in various oceanographic regions. Furthermore, since consumers are most successful (i.e. productive and healthy) when consuming phytoplankton of similar stoichiometry to themselves, it is likely that shifts in phytoplankton species (and thus stoichiometry) could result in changes in trophic transfer efficiency (Andersen et al., 2004). Nutrients are a key determinant in phy- toplankton growth and carbon allocation and emerging research (see Wagner et al., 2016; Sackett et al., 2015) has shown that the macromolucular fingerprint of a cell can provide a 'snapshot' prediction of carbon efficiency (Sackett et al., 2015). This new insight and methodology delivers a promising biomarker for predicting growth and productivity, and is worthy of further investigation.

\subsection{Ocean acidification $-\mathrm{pH}$ and $\mathrm{CO}_{2}$}

Photosynthetic carbon fixation by marine phytoplankton is constrained by low $\mathrm{CO}_{2}$ concentrations present in ocean surface waters $(<10-30 \mu \mathrm{M})$, caused by the low equilibrium concentrations and slow diffusion rates into the cell. Further restrictions to $\mathrm{CO}_{2}$ uptake are imposed by the slow turnover rate and low affinity to $\mathrm{CO}_{2}$ of RubisCO, which is central to the Calvin cycle. To overcome these limitations and maintain high rates of photosynthesis, marine phytoplankton use a carbon concentrating mechanism (CCM, Reinfelder, 2011). The induction of a CCM involves the active uptake of $\mathrm{CO}_{2}$ and/or bicarbonate $\left(\mathrm{HCO}_{3}{ }^{-}\right)$and the activity of extraand/or intracellular carbonic anhydrase (CA), an enzyme that catalyses the reversible dehydration of $\mathrm{HCO}_{3}{ }^{-}$to $\mathrm{CO}_{2}$ and vice versa. Extracellular $\mathrm{CA}$ is thought to sustain inorganic carbon uptake by generating $\mathrm{CO}_{2}$ at the cell surface, a process that is of particular importance under low $\mathrm{CO}_{2}$ conditions (Badger and Price, 1994; Hopkinson et al., 2013). As active uptake of $\mathrm{HCO}_{3}{ }^{-}$and $\mathrm{CO}_{2}$ results in the concentration of inorganic carbon inside cells in excess of that in seawater, the ability for phytoplankton to minimise the $\mathrm{CO}_{2}$ loss out of the cell also represents an important component of the CCM (Rost et al., 2006).

The extent to which lowered $\mathrm{pH}$ and elevated $\mathrm{CO}_{2}$ concentrations in seawater will alter carbon acquisition and photosynthetic carbon fixation in phytoplankton strongly depends on the physiological mechanisms of inorganic carbon uptake and intracellular assimilation. In response to lowered $\mathrm{pH}$, studies have shown a down-regulation of the $\mathrm{CCM}$, e.g. decreased uptake rates of $\mathrm{CO}_{2}$ and $\mathrm{HCO}_{3}{ }^{-}$as well as lowered external CA activities (see Reinfelder, 2011). Natural phytoplankton communities of the SO (Weddell Sea, Drake Passage, Western Antarctic Peninsula, Amundsen and Ross Sea) were found to actively take up $\mathrm{CO}_{2}$ and $\mathrm{HCO}_{3}{ }^{-}$(Cassar et al., 2004; Tortell et al., 2008a, 2008b, 2010; Neven et al., 2011; Tortell et al., 2013; Kranz et al., 2015; Trimborn et al., 2015), thus indicating the presence of a CCM. Also, laboratory studies have demonstrated the operation of CCMs in various SO diatoms (Chaetoceros debilis, Fragilariopsis kerguelensis, F. cylindrus, Nitzschia frigida, Pseudo-nitzschia subcurvata) and a prymnesiophyte (Phaeocystis antarctica), although important differences between species were seen in the ratios of $\mathrm{HCO}_{3}{ }^{-}$and $\mathrm{CO}_{2}$ uptake and external CA activity (Mitchell and Beardall, 1996; Trimborn et al., 2013; Kranz et al., 2015; Young et al., 2015).

Lowered $\mathrm{pH}$ and elevated $\mathrm{CO}_{2}$ concentrations in seawater are considered to favour the growth of species that thrive under higher diffusive $\mathrm{CO}_{2}$ uptake and have lower $\mathrm{CO}_{2}$ leakage from the cell. Even though carbon fixation rates of SO phytoplankton species with highly efficient CCMs are already close to saturation under presentday $\mathrm{CO}_{2}$ concentrations (Trimborn et al., 2013; Kranz et al., 2015; Young et al., 2015), lower energy expenditures, as well as optimised resource allocation resulting from CCM down-regulation, may enable enhanced carbon fixation rates and/or growth at lowered $\mathrm{pH}$ levels. Under these conditions, temperate diatom species, being characterised to operate highly efficient CCMs (Burkhardt et al., 2001; Roberts et al., 2007; Trimborn et al., 2008, 2009), were estimated to save about $20 \%$ of the CCM-related energy expenditure and $3-6 \%$ of the energy expended on carbon fixation (Hopkinson et al., 2011). Among tested SO phytoplankton species, $\mathrm{CO}_{2}$-dependent responses on growth strongly vary. For one Antarctic sea ice diatom (Nitzschia lecointei), growth was 
slightly stimulated from ambient to low $\mathrm{pH}$ levels in short-term experiments (Torstensson et al., 2013), but long-term acclimation ( $\sim 200$ days) under these conditions resulted in a reduction in growth by $3-4 \%$ (Torstensson et al., 2015). However, growth and/or carbon fixation of other diatoms ( $C$. brevis, $C$. debilis, Rhizosolenia cf. alata, P. subcurvata and P. alata) and P. antarctica remained unaffected by lowered pH (Riebesell et al., 1991; Boelen et al., 2007; Hoogstraten et al., 2012; Trimborn et al., 2013; Hoppe et al., 2015) suggesting that overall, the SO phytoplankton species investigated do not seem to benefit from lowered $\mathrm{pH}$ levels.

Natural phytoplankton assemblages of the SO can be susceptible to lowered $\mathrm{pH}$, both in terms of community structure and productivity (Tortell et al., 2008a; Feng et al., 2010; Hoppe et al., 2013). Lowered $\mathrm{pH}$ promoted the growth of diatoms and a floristic shift from pennate Pseudo-nitzschia (Tortell et al., 2008a; Hoppe et al., 2013) or Cylindrotheca (Feng et al., 2010) dominated assemblages to communities dominated by Chaetoceros (Tortell et al., 2008a; Feng et al., 2010) or Fragilariopsis (Hoppe et al., 2013). Although Chaetoceros did not dominate the assemblage in one of the studies (Hoppe et al., 2013), a 50\% increase in its relative abundance was observed, pointing towards a pH-dependent stimulation of growth for this genus. These floristic shifts were also accompanied by an increase in carbon fixation (Tortell et al., 2008a; Hoppe et al., 2013), which could either be related to higher diffusive carbon supply or lowered energetic costs of carbon acquisition under lowered $\mathrm{pH}$ (Rost et al., 2008).

Energetic benefits resulting from lowered $\mathrm{pH}$ may be especially important under growth limiting conditions such as iron- or lightlimitation as frequently observed in the SO (Timmermans et al., 2001; Feng et al., 2010; Petrou et al., 2011b; Strzepek et al., 2012). At present, only two studies on SO species have examined the physiological influence of $\mathrm{pH}$ and light in combination, finding that neither the exposure to limiting nor to saturating irradiance levels modulated $\mathrm{pH}$-specific growth responses of the Antarctic diatoms $P$. alata (Hoogstraten et al., 2012) and C. brevis (Boelen et al., 2007). Similarly, under both constant and fluctuating light no significant pH-effects on growth were observed in C. brevis (Boelen et al., 2007) and $C$. debilis (Hoppe et al., 2015). In the latter study, however, dynamic light and lowered $\mathrm{pH}$ synergistically lowered carbon fixation, potentially due to higher metabolic costs for photoacclimation and PSII repair. Information on interactive effects of iron ( $\mathrm{Fe})$ and lowered $\mathrm{pH}$ is still very limited. In line with earlier field studies (Tortell et al., 2008a; Feng et al., 2010), Hoppe et al. (2013) reported that both Fe enrichment and lowered $\mathrm{pH}$ increased primary production and triggered a shift away from weakly to heavily silicified SO diatoms (Pseudo-nitzschia sp. and Fragilariopsis sp. at pH levels of 8.03 and 7.74, respectively). Under Fe-limitation, however, primary production remained unaltered at lowered $\mathrm{pH}$ while thinly silicified diatoms dominated irrespective of the applied $\mathrm{pH}$ level (Pseudo-nitzschia sp. and Synedropsis sp. at pH levels of 8.03 and 7.74, respectively, Hoppe et al., 2013).

Low Fe combined with high light conditions strongly affect Antarctic phytoplankton physiology (e.g. decreased growth, photosynthesis and carbon fixation (Timmermans et al., 2001; Feng et al., 2010; Petrou et al., 2011b; Strzepek et al., 2012), combined with lowered $\mathrm{pH}$, these conditions could impose even stronger stresses for phytoplankton. In temperate phytoplankton, it has been shown that elevated $\mathrm{pH}$ potentially increases the degree of Fe-limitation (Shi et al., 2010), where the pH-dependent changes in Fe chemistry presumably influenced the observed shift in species composition (Hoppe et al., 2013). Natural phytoplankton assemblages from the Ross Sea responded strongly to changing irradiance and Fe and to a much lesser degree to elevated pH (Feng et al., 2010). However, a recent study on the interactive effects of $\mathrm{pH}$, light, temperature and $\mathrm{Fe}$ on growth and primary productivity of $P$. antarctica and $F$. cylindrus, found that these species may actually increase their
Fe requirement relative to carbon fixation under elevated $\mathrm{pH}$ and increased temperature conditions (Xu et al., 2014).

The last decade of research has resulted in considerable advances in our understanding of the physiological responses of phytoplankton to changes in seawater carbonate chemistry, including a number of mesocosm studies with natural marine communities. The varied results from these studies, however, highlight the complexity involved in understanding biological responses to OA. While logistically challenging, future research needs to extend the complexity of the studies and assess community changes in response to combined stressors, as low $\mathrm{pH}$ will not occur in isolation of the multiple changes predicted for the marine environment, nor will species respond in isolation of other species.

\subsection{Iron $(\mathrm{Fe})$ limitation}

In the modern ocean, $\mathrm{Fe}$ is rapidly oxidised from the soluble Ferrous iron $\left(\mathrm{Fe}_{(\mathrm{II})}\right)$ to the highly insoluble $\mathrm{Fe}_{(\mathrm{III})}$ and ferric hydroxide species, which are rapidly exported to depth by aggregation and scavenging. In phytoplankton, Fe is an essential micronutrient for photosynthesis, required in Chlorophyll $a$, photosystem I (PSI), photosystem II (PSII), cytochrome $b_{6}-f$ complex, cytochrome $c_{6}$, ferredoxin and Nicotinamide Adenine Dinucleotide Phosphate $(\mathrm{NAD}(\mathrm{P}) \mathrm{H})$ dehydrogenase (Raven et al., 1999; Behrenfeld and Milligan, 2013). Additionally, Fe is involved in other key cellular processes such as respiration, macronutrient assimilation and detoxification of reactive oxygen species (Sunda, 1989; Morel et al., 1991; Sunda and Huntsman, 1995). Due to their high demand for Fe, primary producers have developed specialised mechanisms to satisfy their needs; resulting in a decoupling between intracellular and dissolved Fe stoichiometry (Morel and Price, 2003; Moore et al., 2013), as well as complex interactions and feedbacks between Fe biology and its chemistry (Hassler et al., 2011a).

Over 30 years of research has demonstrated that Fe limitation controls the efficiency of the biological pump and the structure of phytoplankton communities in the SO (e.g., Martin, 1990; Coale et al., 2003; De Baar et al., 2005; Maldonado et al., 2005; Blain et al., 2007; Boyd et al., 2007; Smetacek et al., 2012). However, only the biologically active pool (defined here as bioavailable) is the fraction that can be effectively taken up by microorganisms to support their nutrient-dependent metabolic processes and growth (Hassler et al., 2012). Enrichment of Fe can drive shifts in the community structure from a nanoplankton $(<10 \mu \mathrm{m})$ to a microplankton $(>10 \mu \mathrm{m})$ dominated assemblage (De Baar et al., 2005), increasing the sinking of particulate organic carbon (POC) and thus export to the deep ocean (Boyd et al., 2000). As such, it is the bioavailable pool that shapes SO phytoplankton communities and caps the efficiency of the biological pump.

Across the SO, low bioavailability in Fe means that microorganisms are in competition to satisfy their biological requirement for growth. For that purpose, phytoplankton have evolved various strategies such as a reduction in cell size, induction of high affinity transporters and overexpression of surface proteins or siderophores (Maldonado and Price, 1999; Trick and Wilhelm, 1995; Mioni et al., 2005) to acquire Fe and modulate their requirement. Microorganisms can also modulate their Fe biological requirement using enzyme replacement and modification of the photosynthetic antenna (Behrenfeld and Milligan, 2013; Petrou et al., 2014). Diatoms exhibit the highest sensitivity to Fe limitation (Miller et al., 1991; Morel et al., 1991) with shifts to larger sizes $(>10 \mu \mathrm{m})$ in response to Fe fertilisation (De Baar et al., 2005). Experiments carried out with cultured diatoms in the laboratory showed a relationship between Fe, the surface/volume ratio $(S / V)$ and the iron biological requirement for growth (De Baar et al., 2005; Timmermans et al., 2004; Sarthou et al., 2005), with larger diatoms being associated with greater iron requirement. Therefore, 
Fe bioavailability is not only influenced by its chemical forms, but also by the different uptake strategies, biological requirements and interactions of the phyto- and bacterio-plankton communities (e.g., Barbeau et al., 1996; Hutchins et al., 1999).

The amount of inorganic, bioavailable $\mathrm{Fe}$ in the SO is often insufficient to solely sustain phytoplankton growth (Hassler et al., 2012), as more than 99\% of the dissolved Fe is associated with dissolved organic ligands (e.g., Boyd and Ellwood, 2010; Hassler et al., 2012). Fe-binding organic ligands are critical for Fe biogeochemistry, improving its solubility and affecting its reactivity to support phytoplankton growth (Maldonado et al., 2005; Hassler et al., 2011a, 2012). The distribution of Fe-binding organic ligands in the open ocean is compatible with multiple biological sources associated with Fe-stress and its recycling/remineralisation (Hunter and Boyd, 2007). However, despite their recognised importance, the production pathways, nature and binding mechanisms of insitu Fe-binding ligands are mostly unknown (Gledhill and Buck, 2012).

The recycling of Fe (and iron-binding ligands) is rapid (hours to days) and occurs through grazing, phytoplankton lysis, bacterial and viral infections (Barbeau et al., 1996; Poorvin et al., 2004; Strzepek et al., 2005), as well as active excretion and transformation of organic compounds (e.g., Trick and Wilhelm, 1995; Ogawa et al., 2001; Hassler et al., 2011b). In the remote SO where external sources of Fe are limited, Fe recycling is efficient, providing $20-100 \%$ of the Fe required to sustain phytoplankton growth (Hutchins et al., 1993; Poorvin et al., 2004; Strzepek et al., 2005; Sarthou et al., 2005). Remineralisation of particulate Fe at depth mediated by heterotrophic bacteria can also release Fe and ligands (Boyd et al., 2010), thus potentially affecting Fe bioavailability to primary producers. Moreover, microorganisms can affect Fe redox chemistry, either by direct reduction of an Fe organic complex (often resulting in $\mathrm{Fe}_{(\mathrm{II})}$ complexes easier to dissociate; e.g., Shaked et al., 2005) or by the excretion of compounds such as superoxide (Kutska et al., 2005). Despite numerous studies, the parameters controlling the bioavailability of Fe to SO primary producers remains poorly understood (Boyd and Ellwood, 2010; Hassler et al., 2011a).

Considering the complexity of the feedback between Fe chemistry, biological responses to Fe limitation, the specificity of Fe biological requirement, and biological interactions at play, predicting changes to Fe bioavailability under future climate remains a challenging task. First, changes in Fe input rates in the SO could be related to changes in important current sources, including precipitation, atmospheric dust deposition and sea ice melting (e.g., Lizotte, 2001; Lannuzel et al., 2008; Moore and Braucher, 2008; Boyd and Ellwood, 2010). Secondly, warmer temperatures and ocean acidification (OA) will directly affect Fe chemistry, namely its solubility and strength of complexation with organic ligands (Millero, 2009; Breitbarth et al., 2010; Hassler et al., 2013; Gledhill et al., 2015). In artificial seawater ( $\mathrm{pH} 8.1$ ) Fe solubility decreased from $0.5 \mathrm{nM}$ at $5{ }^{\circ} \mathrm{C}$ to $0.03 \mathrm{nM}$ at $25^{\circ} \mathrm{C}$ (Liu and Millero, 1999). In contrast, the ratio between the concentrations of inorganic Fe to $\mathrm{Fe}_{(\mathrm{III})}$ increased by 1.16 -fold for each $1^{\circ} \mathrm{C}$ increment (Byrne et al., 1998). Therefore, it is unclear how an increase in temperature will affect Fe bioavailability. As oceans become more acidic, both the hydroxide $\left(\mathrm{OH}^{-}\right)$and carbonate $\left(\mathrm{CO}_{3}{ }^{2-}\right)$ ions that form strong complexes with $\mathrm{Fe}$, are expected to decrease, dropping by up to $80 \%$ by the end of the millennium (Millero, 2009). Therefore, a decrease in $\mathrm{pH}$ would contribute not only to an increase in the concentration of dissolved inorganic $\mathrm{Fe}, \mathrm{Fe}_{(\mathrm{II})}$ concentrations, and $\mathrm{Fe}_{(\mathrm{II})}$ half-life times, but also to a weakening of Fe binding with ligands (Millero, 2009; Breitbarth et al., 2010; Gledhill et al., 2015), all of which should result in increased Fe bioavailability. However, to date, studies using diatom cultures and natural assemblages from the SO have shown that Fe bioavailability was decreased under the OA scenario (Shi et al., 2010; Hoppe et al., 2013; Sugie and Yoshimura, 2013; Sugie et al., 2013). This indicates that, while changes to physico-chemical conditions in the future are reasonably well characterised for inorganic Fe species, it is not the case for in-situ organic species (Gledhill et al., 2015). Given that more than $99 \%$ of $\mathrm{Fe}$ is associated with loosely characterised organic ligands, many uncertainties remain with respect to understanding changes to Fe bioavailability based on its chemistry. Furthermore, both $\mathrm{OA}$ and temperature can affect biological growth and generation of organic ligands, potentially favouring growth of specific phytoplankton species and inducing a shift in the community structure unrelated to Fe (e.g., Tortell et al., 2008a; Trimborn et al., 2014). As different biological communities excrete different iron-binding ligands (Trick and Wilhelm, 1995; Maldonado et al., 2002; Hassler et al., 2015; Norman et al., 2015), a shift in community structure or changes in Fe-stress could have a greater impact on Fe chemistry and bioavailability than those associated with changes in temperature and $\mathrm{pH}$ (Gledhill et al., 2015). However, the effect that the modulation of the excretion of organic ligands associated with basal biological activity or the change in the nature of organic ligands associated with a shift in community will have on Fe chemistry and bioavailability is yet to be investigated.

The implication of changes in Fe bioavailability, (floristic shifts and primary productivity) is highly dependent on the changes in co-varying environmental parameters, all of which will likely influence oceanic carbon recycling and export (Shi et al., 2010; Hoppe et al., 2013). Fe limitation and OA can alter the extent of diatom silicification (Franck et al., 2000) and thus their contribution to carbon export (Hoppe et al., 2013). Similarly, light is also known to affect Fe limitation (Timmermans et al., 2001; Petrou et al., 2011b, 2014) and different taxa could be controlled by other trace elements (e.g., Zn and Co for Phaeocystis antarctica; Saito and Goepfert, 2008), suggesting that multiple "stressors" need to be simultaneously accounted for in order to predict future changes in Fe bioavailability and primary productivity, something that has only recently started to be investigated (Boyd et al., 2015).

\section{Future of SO primary productivity?}

There is ample evidence that climate change will shape the function and ecology of phytoplankton of the future, influencing their composition, abundance, distribution, phenology and physiology (Falkowski et al., 2004; Strzepek and Harrison, 2004) and that this process has already begun (Polovina et al., 2008; Doney et al., 2009; Constable et al., 2014). Yet the magnitude, and even the nature, of those changes remain unclear. In the SO, projected changes in nutrient supply and light climate, as a result of stratification, will likely result in regional changes in net primary productivity (NPP), where previously light-limited areas could see an increase in NPP (Doney, 2006; Arrigo and Thomas, 2004), whereas in nutrient-limited areas, NPP may decline (Arrigo and Thomas, 2004). Of course, these simplistic projections are made more complex by the biota and its physiological response to altered conditions, as any resultant shift in species composition will not only influence productivity, but also trophodynamics and biogeochemistry. If communities shift from diatom dominated to non-diatom dominated populations, an increase in primary production rates may occur, as nutrient utilisation efficiency and carbon fixation is generally lower in diatoms (Arrigo et al., 1999). However, smaller non-silicified cells may have lower sinking rates and therefore weaken the biological pump and reduce carbon sequestration. In addition, the effect of $\mathrm{OA}$ brings an added complexity to understanding the way communities will shift and respond and how this will influence food webs and carbon sequestration. 


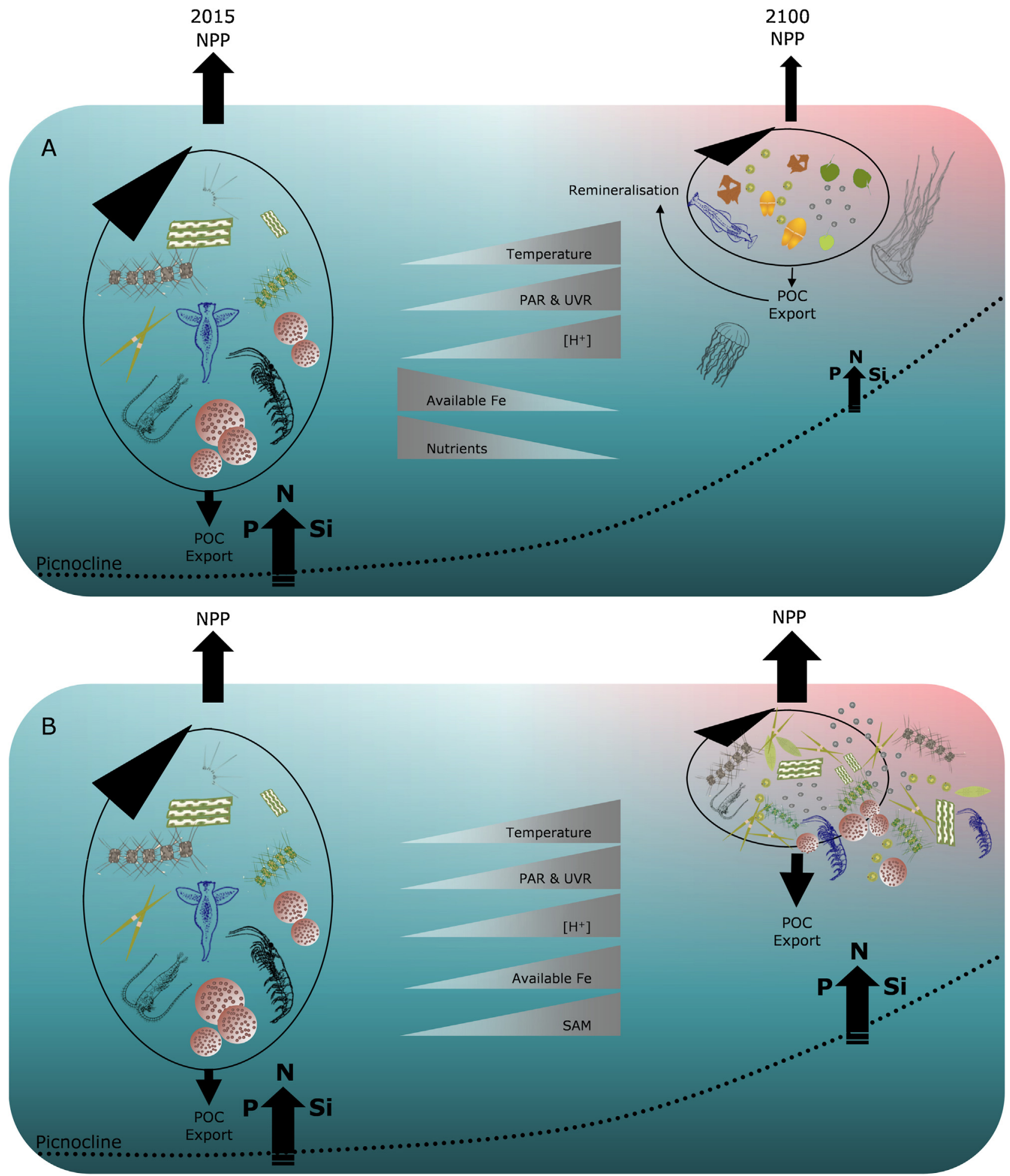

Fig. 4. Cartoon illustrating possible scenarios for SO net primary productivity (NPP) today and at the end of the twenty-first century (2100). (A) Ocean shoaling leads to reduced nutrient input, changing species composition and trapping phytoplankton in warm, nutrient-poor, high UVR waters. These conditions result in large floristic shifts to smaller, flagellate species, reducing POC export and high rates of damage to photosynthesis from UVR exposure, reducing overall NPP. (B) Ocean shoaling is diminished by increased positive SAM index, enhancing upwelling and delivering nutrients to well-lit, surface waters, promoting phytoplankton growth and boosting NPP. Increased Fe bioavailability maintains a high diatom diversity (minimal floristic shift) and silicification, resulting in high POC export to the deep ocean. In both scenarios the increase in hydrogen ions $\left[\mathrm{H}^{+}\right]$results in a loss of calcifying organisms.

Ocean warming and the subsequent diminishing of the MLD will influence SO primary productivity in the future, but the extent and direction of this change is still unclear. Based on the existing knowledge of predicted climate forcing and phytoplankton physiology, two opposing scenarios can be derived (Fig. 4): in the first scenario, the shoaling of the ocean leads to a reduction in macronutrient input from the deep and there is a diminishing supply of bioavailable Fe, either from the loss in sea ice as a source or from the effects of warming on Fe solubility (Liu and Millero, Liu and Millero, 1999). Under these conditions, phytoplankton are trapped

Please cite this article in press as: Petrou, K., et al., Southern Ocean phytoplankton physiology in a changing climate. J Plant Physiol (2016), http://dx.doi.org/10.1016/j.jplph.2016.05.004 
in warm, macro- and micronutrient-poor surface waters (Fig. 4a) where they are exposed to high light and damaging UV radiation (Marinov et al., 2010), likely reducing rates of phytoplankton photosynthesis, growth and NPP. These future conditions also favour phytoplankton communities typical of the POOZ, which contribute little to POC export, weakening the biological pump (Fig. 4a). In the second scenario (Fig. 4b), climate-induced physical and chemical changes to the SO increase the bioavailability of Fe due to warming (Byrne et al., 1998) and lowered pH (Millero, 2009; Breitbarth et al., 2010; Gledhill et al., 2015) and favour the increase in the prevalence of large diatoms. In addition, the intensification of westerly winds, due to the increasing positive SAM index (Fig. 4b), drive upwelling and thus nutrient supply to the surface waters, alleviating nutrient-limitation and increasing diatom abundance (Alvain et al., 2013; Rousseaux and Gregg, 2015). In combination, such conditions enhance NPP in the SO, through faster growth rates and minimal floristic shifts, maintaining high POC export and efficient ocean biogeochemical cycling.

To date, nearly all phytoplankton physiological studies have constrained their manipulations to one or two variables, providing information on a species' response to individual or dual environmental stressors. These studies, while valuable, lack the validity and relevance to assess global change at the ecological scale, as they do not test the effects of multiple stressors, nor indeed, multiple species. The inherent spatial heterogeneity in climatemediated changes to physico-chemical conditions of the ocean and the specificity of species' physiological responses to individual and combined stressors, makes understanding how climate change will influence SO phytoplankton physiology, community structure, biogeochemistry, NPP and ultimately the efficacy of the SO as a carbon sink, an ongoing challenge.

\section{References}

Almandoz, G.O., Ferreyra, G.A., Schloss, I.R., Dogliotti, A.I., Rupolo, V., Paparazzo, F.E., et al., 2008. Distribution and ecology of Pseudo-nitzschia species (Bacillariophyceae) in surface waters of the Weddell Sea (Antarctica). Polar Biol. 31, 429-442

Alvain, S., Moulin, C., Dandonneau, Y., Loisel, H., 2008. Seasonal distribution and succession of dominant phytoplankton groups in the global ocean: a satellite view. Global Biogeochem. Cycles, 22.

Alvain, S., Le Quéré, C., Bopp, L., Racault, M.F., Beaugrand, G., Dessailly, D., Buitenhuis, E.T., 2013. Rapid climatic driven shifts of diatoms at high latitudes. Remote Sens. Environ. 132, 195-201.

Andersen, T., Elser, J.J., Hessen, D.O., 2004. Stoichiometry and population dynamics. Ecol. Lett. 7, 884-900.

Armbrust, E.V., 2009. The life of diatoms in the world's oceans. Nature 459, $185-192$.

Arrigo, K.R., Thomas, D.N., 2004. Large scale importance of sea ice biology in the Southern Ocean. Antarct. Sci. 16, 471-486.

Arrigo, K.R., Worthen, D.L., Dixon, P., Lizotte, M.P., 1998. Primary productivity of near surface communities within Antarctic pack ice. In: Lizotte, M.P., Arrigo, K.R. (Eds.), Antarctic Sea Ice: Biological Processes, Interactions, and Variability, vol. 73. AGU Antarctic Research Series, Washington DC, pp. 23-43.

Arrigo, K., Worthen, D., Dunbar, R.B., DiTullio, G.R., Vanwoert, M., Lizotte, M., 1999. Phytoplankton community structure and the drawdown of nutrients and $\mathrm{CO}_{2}$ in the Southern Ocean. Science 283, 365-367.

Arrigo, K.R., van Dijken, G.L., Long, M., 2008a. Coastal southern ocean: a strong anthropogenic CO2 sink. Geophys. Res. Lett., http://dx.doi.org/10.1029/ 2008gl035624, L21602.

Arrigo, K.R., van Dijken, G.L., Bushinsky, S., 2008b. Primary production in the southern ocean, 1997-2006. J. Geophys. Res. Oceans 113, C8, http://dx.doi.org/ 10.1029/2007jc004551, Artn C08004.

Arrigo, K.R., Mock, T., Lizotte, M.P., 2010. Primary producers and sea ice. In: Thomas, D.N., Dieckmann, G. (Eds.), Sea Ice. , 2nd edition. Oxford: Wiley-Blackwell, pp. 283-326.

Arrigo, K.R., Perovich, D.K., Pickart, R.S., Brown, Z.W., vanDijken, G.L., Lowry, K.E., et al., 2012. Massive phytoplankton blooms under Arctic sea ice. Science 336, 1408, http://dx.doi.org/10.1126/science.1215065.

Arrigo, K.R., 2005. Marine microorganisms and global nutrient cycles. Nature 437, 349-355.

Bélanger, S., Babin, M., Tremblay, J.-E., 2013. Increasing cloudiness in Arctic damps the increase in phytoplankton primary production due to sea ice receding. Biogeosciences 10, 4087-4101.
Badger, M.R., Price, D., 1994. The role of carbonic anhydrase in photosynthesis. Annu. Rev. Plant Physiol. Plant Mol. Biol. 45, 369-392.

Barbeau, K., Moffett, J.W., Caron, D.A., Croot, P.L., Erdner, D.L., 1996. Role of protozoan grazing in relieving iron limitation of phytoplankton. Nature 380, 61-64.

Beans, C., Hecq, J.H., Koubbi, P., Vallet, C., Wright, S., Goffart, A., 2008. A study of the diatom-dominated microplankton summer assemblages in coastal waters from Terre Adeílie to the Mertz Glacier, East Antarctica (139E-145E). Polar Biol. 31, 1101-1117.

Behrenfeld, M.J., Milligan, A.J., 2013. Photophysiological expressions of iron stress in phytoplankton. Ann. Rev. Mar. Sci. 5, 217-246.

Behrenfeld, M.J., O’Malley, R.T., Siegel, D.A., McClain, C.R., Sarmiento, J.L., Feldman, G.C., et al., 2006. Climate-driven trends in contemporary ocean productivity. Nature 444, 752-755.

Behrenfeld, M.J., Falkowski, P.J., 1997. Photosynthetic rates derived from satellite-based chlorophyll concentration. Limnol. Oceanogr. 42, $1-20$.

Blain, S., Queguiner, B., Armand, L., Belviso, S., Bombled, B., Bopp, L., et al., 2007. Impacts of natural iron fertilisation on the Southern Ocean. Nature 46, 1070-1074.

Boelen, P., van de Poll, W.H., van der Strate, H.J., Neven, I.A., Beardall, J., Buma, A.G.J., 2007. Neither elevated nor reduced CO2 affects the photophysiological performance of the marine Antarctic diatom Chaetoceros brevis. J. Exp. Mar. Biol. Ecol. 406, 38-45.

Bopp, L., Monfray, P., Aumont, O., Dufresne, J.-L., Le Treut, H., Madec, G., et al., 2001. Potential impact of climate change on marine export production. Global Biogeochem. Cycles 15, 81-99.

Boyd, P.W., Doney, S., 2002. Modelling regional responses by marine pelagic ecosystem to global climate change. Geophys. Res. Lett. 29, 1-53.

Boyd, P., Ellwood, M., 2010. The biogeochemical cycle of iron in the ocean. Nat. Geosci. 3, 675-682.

Boyd, C.M., Heyraud, M., Boyd, C.N., 1984. Feeding of the Antarctic krill Euphausia superba. J. Crustac. Biol. 4, 123-141.

Boyd, P.W., Watson, A.J., Law, C.S., Abraham, E.R., Trull, T., Murdoch, R., et al., 2000. A mesoscale phytoplankton bloom in the polar Southern Ocean stimulated by iron fertilization. Nature 407, 695-702.

Boyd, P.W., Jickells, T., Law, C., Blain, S., Boyle, E., Buesseler, K., et al., 2007. Mesoscale iron enrichment experiments 1993-2005: Synthesis and future directions. Science 315, 612-617.

Boyd, P.W., Doney, S.C., Strzepek, R., Dusenberry, J., Lindsay, K., Fung, I., 2008. Climate mediated changes to mixed-layer properties in the Southern Ocean: assessing the phytoplankton response. Biogeosciences 5, 847-864.

Boyd, P.W., Arrigo, K.R., Strzepek, R., van Dijken, G.L., 2010. Mapping phytoplankton iron utilization: insights into Southern Ocean supply mechanisms. J. Geophys. Res., 117, C06009.

Boyd, P.W., Rynearson, T.A., Armstrong, E.A., Fu, F., Hayashi, K., Hu, Z., et al., 2013. Marine phytoplankton temperature versus growth responses from polar to tropical waters - outcome of a scientific community-wide study. PLoS One 8 (5), e63091, http://dx.doi.org/10.1371/journal.pone.0063091.

Boyd, P.W., Dillingham, P.W., McGraw, C.M., Armstrong, E.A., Cornwall, C.E., Feng -y, Y., et al., 2015. Physiological responses of a Southern Ocean diatom to complex future ocean conditions. Nat. Clim. Change, http://dx.doi.org/10.1038 NCLIMATE2811.

Boyd, P.W., 2002. Environmental factors controlling phytoplankton processes in the Southern Ocean. J. Phycol. 38, 844-861.

Boyd, P.W., 2013. Framing biological responses to a changing climate. Nat. Clim. Change 3, 530-533.

Breitbarth, E., Bellerby, R., Neill, C., Ardelan, M., Meyerhöfer, M., Zöllner, E., et al., 2010. Ocean acidification affects iron speciation during a coastal seawater mesocosm experiment. Biogeoscience 7, 1065-1073.

Brussaard, C.P.D., Noordeloos, A.A.M., Witte, H., Collenteur, M.C.J., Schulz, K.G., Ludwig, A., Riebesell, U., 2013. Arctic microbial community dynamics influenced by elevated CO2 levels. Biogeoscience 10, 719-731.

Bryant, D.A., 2003. The beauty in small things revealed. Proc. Natl. Acad. Sci 100 9647-9649.

Buesseler, K.O., 1998. The decoupling of production and particulate export in the surface ocean. Global Biogeochem. Cycles 12, 297-310.

Burkhardt, S., Amoroso, G., Riebesell, U., Sültemeyer, D., 2001. CO2 and HCO3uptake in marine diatoms acclimated to different CO2 concentrations. Limnol. Oceanogr. 46, 1378-1391.

Byrne, R.H., Kump, L.R., Cantrell, K.J., 1998. The influence of temperature and pH on trace metal speciation in seawater. Mar. Chem. 25, 163-181.

Caron, D.A., Hutchins, D.A., 2013. The effects of changing climate on microzooplankton grazing and community structure: drivers, predictions and knowledge gaps. J. Plankton Res. 35, 235-252.

Cassar, N., Laws, E.A., Bidigare, R.R., Popp, B.N., 2004. Bicarbonate uptake by southern ocean phytoplankton. Global Biogeochem. Cycles, 18, http://dx.doi. org/10.1029/2003GB002116.

Chen, B., Landry, M.R., Huang, B., Liu, H., 2012. Does warming enhance the effect of microzooplankton grazing on marine phytoplankton in the ocean? Limnol. Oceanogr. 57, 519-526.

Coale, K.H., Wang, X., Tanner, S.J., Johnson, K.S., 2003. Phytoplankton growth and biological response to iron and zinc addition in the Ross Sea and Antarctic Circumpolar Current along 170 W. Deep Sea Res. Part II 50, 635-653. 
Coale, K.H., Johnson, K.S., Chavez, F.P., Buesseler, K.O., Barber, R.T., Brzezinski, M.A., et al., 2004. Southern Ocean iron enrichment experiment: carbon cycling in high-and low-Si waters. Science 304, 408-414.

Constable, A.J., Melbourne-Thomas, J., Corney, S.P., Arrigo, K.R., Barbraud, C., Barnes, D.K.A., et al., 2014. Climate change and Southern Ocean ecosystems I: how changes in physical habitats directly affect marine biota. Global Change Biol., http://dx.doi.org/10.1111/gcb.12623.

Critchley, C., 1997. Regulation of photosynthetic pigments in micro-algae by multiple environmental factors: a dynamic balance hypothesis. New Phytol 137, 629-638.

Cubillos, J.C., Wright, S.W., Nash, G., De Salas, M.F., Griffiths, B., Tilbrook, B., et al., 2007. Calcification morphotypes of the coccolithophorid Emiliania huxleyi in the Southern Ocean: changes in 2001 to 2006 compared to historical data. Mar Ecol. Prog. Ser. 348, 47-54.

Davidson, A.T., Scott, F.J., Nash, G.V., Wright, S.W., Raymond, B., 2010. Physical and biological control of protistan community composition, distribution and abundance in the seasonal ice zone of the Southern Ocean between 30 and 80 E. Deep Sea Res. II 57, 828-848.

Davidson, A., McKinlay, J., Westwood, K., Thomson, P., van den Enden, R., de Salas, M., Wright, S., Johnson, R., Berry, K., Tillbrook, B., 2016. Enhanced C concentrations change the structure of Antarctic marine microbial communities. Mar. Ecol. Prog. Ser., O2, http://dx.doi.org/10.3354/meps11742.

Davidson, A.T., 2006. Effects of ultraviolet radiation on microalgal growth, survival and production. In: Rao, S.D.V. (Ed.), Algal Cultures, Analogues of Blooms and Applications. Science Publishers Inc., New Hamshire, USA, pp. 715-768.

De Baar, H.J., Boyd, P.W., Coale, K.H., Landry, M.R., Tsuda, A., Assmy, P., et al., 2005. Synthesis of iron fertilization experiments: from the iron age in the age of enlightenment. J. Geophys. Res. Oceans 110, C9.

Delille, B., Vancoppenolle, M., Geilfus, N.-X., Tilbrook, B., Lannuzel, D., Schoemann, V., et al., 2014. Southern Ocean $\mathrm{CO}_{2}$ sink: the contribution of the sea ice. J. Geophys. Res. Oceans 119, http://dx.doi.org/10.1002/2014JC009941.

Dennett, M.R., Mathot, S., Caron, D.A., Smith Jr, W.O., Lonsdale, DJ., 2001. Abundance and distribution of phototrophic and heterotrophic nano- and microplankton in the southern Ross Sea. Deep Sea Res. II 48, 4019-4037.

Descolas-Gros, C., de Billy, G., 1987. Temperature adaptation of RuBP carboxylase: kinetic properties in marine Antarctic diatoms. J. Exp. Mar. Biol. Ecol. 108, $147-158$.

Devos, N., Ingouff, M., Loppes, R., Matagne, R.F., 1998. Rubisco adaptation to low temperatures: a comparative study in psychrophilic and mesophilic unicellular algae. J. Phycol. 34, 655-660.

DiTullio, G.R., Grebmeier, J.M., Arrigo, K.R., Lizotte, M.P., Robinson, D.H., Leventer, A., Barry, J.P., VanWoert, M.L., Dunbar, R.B., 2000. Rapid and early export of Phaeocystis antarctica blooms in the Ross Sea Antarctica. Nature 404, 595-597.

Dimier, C., Corato, F., Tramontano, F., Brunet, C., 2007. Photoprotection and xanthophyll-cycle activity in three marine diatoms. J. Phycol. 43, 937-947.

Domingues, C.M., Church, J.A., White, N.J., Gleckler, P.J., Wijffels, S.E., Barker, P.M. Dunn, J.R., 2008. Improved estimates of upper-ocean warming and multi-decadal sea-level rise. Nature 453, 1090-1093.

Doney, S.C., Fabry, V.J., Feely, R.A., Kleypas, J.A., 2009. Ocean acidification: the other $\mathrm{CO}_{2}$ problem. Ann. Rev. Mar. Sci. 1, 169-192.

Doney, S.C., 2006. Oceanography, plankton in a warmer world. Nature 444, 695-696.

Dutkiewicz, S., Morris, J.J., Follows, M.J., Sciott, J., Levitan, O., Dyhrman, S.T. Berman-Frank, I., 2015. Impact of ocean acidification of the structure of future phytoplankton communities. Nat. Clim. Change, http://dx.doi.org/10.1038/ NCLIMATE2722.

Engel, A., Schulz, K.G., Riebesell, U., Bellerby, R., Delille, B., Schartau, M., 2008. Effects of $\mathrm{CO} 2$ on the particle distribution and phytoplankton abundance during a mesocosm bloom experiment (PeECE II). Biogeoscience 5, 509-521.

Falk-Petersen, S., Sargent, J.R., Henderson, J., Hegseth, E.N., Hop, H., Okolodkov, Y.B., 1998. Lipids and fatty acids in ice algae and phytoplankton from the Marginal Ice Zone in the Barents Sea. Polar Biol. 20, 41-47.

Falkowski, P.G., La Roche, J., 1991. Acclimation to spectral irradiance in algae. J. Phycol. 27, 8-14.

Falkowski, P.G., Oliver, M.J., 2007. Mix and match: how climate selects phytoplankton. Nat. Rev. Microbiol. 5, 813-819.

Falkowski, P.G., Barber, R.T., Smetacek, V., 1998. Biogeochemical controls and feedbacks on ocean primary production. Science 281, 200-206.

Falkowski, P.G., Katz, M.E., Knoll, A.H., Quigg, A., Raven, J.A., Schofield, O., Taylor, F.J.R., 2004. The evolution of modern eukaryotic phytoplankton. Science 305, 354-360.

Feller, G., Gerday, C., 2003. Psychrophilic enzymes: hot topics in cold adaptation. Nat. Rev. Microbiol. 1, 200-208.

Feng, Y., Hare, C.E., Rose, J.M., Handy, S.M., DiTullio, G.R., Lee, P.A., et al., 2010. Interactive effects of iron, irradiance and CO2 on Ross Sea phytoplankton. Deep Sea Res. I 57, 368-383.

Field, C.B., Behrenfeld, M.J., Randerson, J.T., Falkowski, P., 1998. Primary production of the biosphere: integrating terrestrial and oceanic components. Science 281 , 237-240

Finkel, Z.V., Beardall, J., Flynn, K.J., Quigg, A., Rees, T.A., Raven, J.A., 2009. Phytoplankton in a changing world: cell size and elemental stoichiometry. J. Plankton Res., fbp098.

Fitch, D.T., Moore, J.K., 2007. Wind speed influence of phytoplankton bloom dynamics in the Southern ocean marginal ice zone. Geophys. Res. 112, C08006.
Franck, V.M., Brzezinski, M.A., Coale, K.H., Nelson, D.M., 2000. Iron and silicic acid concentrations regulate Si uptake north and south of the Polar Frontal Zone in the Pacific sector of the Southern Ocean. Deep Sea Res. II 47, 3315-3338.

Fyfe, J.C., Boer, G.J., Flato, G.M., 1999. The Arctic and Antarctic oscillations and their projected changes under global warming. Geophys. Res. Lett. 26, 1601-1604.

Garibotti, I.A., Vernet, M., Ferrario, M.E., Smith, R.C., Ross, R.M., Quetin, L.B., 2003a. Phytoplankton spatial distribution patterns along the western Antarctic Peninsula (Southern Ocean). Mar. Ecol. Prog. Ser. 261, 21-39.

Garibotti, I.A., Vernet, M., Kozlowski, W.A., Ferrario, M.E., 2003b. Composition and biomass of phytoplankton assemblages in coastal Antarctic waters: a comparison of chemotaxonomic and microscopic analyses. Mar. Ecol. Prog. Ser. 247, 27-42.

Gledhill, M., Buck, K.N., 2012. The organic complexation of iron in the marine environment: a review. Front. Microbiol., 3.

Gledhill, M., Achterberg, E.P., Li, K., Mohamed, K.N., Rijkenberg, M.J., 2015. Influence of ocean acidification on the complexation of iron and copper by organic ligands in estuarine waters. Mar. Chem. 177, 421-433.

Gloerson, P., Campbe, W.J., Cavalier, D.J., Comiso, J.C., Parkinson, C.L., Zwally, H.J., 1992. Arctic and antarctic sea ice: 178-1987. NASA-SP 511, 290.

Goldman, J.A.L., Kranz, S.A., Young, J.N., Tortell, P.D., Stanley, R.H.R., Bender, M.L., Morel, F.M.M., 2015. Gross and net production during the spring bloom along the Western Antarctic Peninsula. New Phytol. 205, 182-191.

Hallegraeff, G.M., 2010. Ocean climate change, phytoplankton community responses, and harmful algal blooms: a formidable predictive challenge. J. Phycol. 46, 220-235.

Hare, C.E., DiTullio, G.R., Riseman, S.F., Crossley, A.C., Popels, L.C., Sedwick, P.N., Hutchins, D.A., 2007. Effects of changing continuous iron input rates on a Southern Ocean algal assemblage. Deep Sea Res. I Oceanogr. Res. Pap. 54, 732-746.

Hassler, C.S., Schoemann, V., Nichols, C.M., Butler, E.C., Boyd, P.W., 2011a. Saccharides enhance iron bioavailability to Southern Ocean phytoplankton. Proc. Natl. Acad. Sci. 108, 1076-1081.

Hassler, C.S., Alasonati, E., Nichols, C.M., Slaveykova, V., 2011b. Exopolysaccharides produced by bacteria isolated from the pelagic Southern Ocean-Role in Fe binding, chemical reactivity, and bioavailability. Mar. Chem. 123, $88-98$.

Hassler, C.S., Schoemann, V., Boye, M., Tagliabue, A., Rozmarynowycz, M., McKay, R.M.L., 2012. Iron bioavailability in the southern ocean. Oceanogr. Mar. Biol. Ann. Rev. 50,1-64.

Hassler, C.S., Legiret, F.-E., Butler, E.C., 2013. Measurement of iron chemical speciation in seawater at $4 \mathrm{C}$ : the use of competitive ligand exchange-adsorptive cathodic stripping voltammetry. Mar. Chem. 149, 63-73.

Hassler, C.S., Norman, L., Mancuso Nichols, C.A., Clementson, L.A., Robinson, C., Schoeman, V., et al., 2015. Iron associated with exopolymeric substances is highly bioavailable to oceanic phytoplankton. Mar. Chem. 173, 136-147.

Hays, G., Richardson, A.J., Robinson, C., 2005. Climate change and marine phytoplankton. Trends Ecol. Evol. 20, 337-344.

Hessen, D.O., Agren, G.I., Anderson, T.R., Elser, J.J., de Ruiter, P.C., 2004. Carbon sequestration in ecosystems: the role of stoichiometry. Ecology 85, 1179-1192.

Hiscock, M.R., Marra, J., Smith, W.O., Goericke, R., Measures, C.I., Vink, S., et al., 2003. Primary productivity and its regulation in the Pacific Sector of the Southern Ocean. Deep Sea Res. Part I: Top. Stud. Oceanogr. 50, 533-558.

Hoogstraten, A., Timmermans, K.R., de Baar, H.J.W., 2012. Morphological and physiological effects in Proboscia alata (Bacillariophyceae) grown under different light and $\mathrm{CO}_{2}$ conditions of the modern Southern Ocean. J. Phycol. 48, 559-568.

Hopkinson, B.M., Dupont, C.L., Allen, A.E., Morel, F.M., 2011. Efficiency of the $\mathrm{CO}_{2}$-concentrating mechanism of diatoms. Proc. Natl. Acad. Sci. 108, 3830-3837.

Hopkinson, B.M., Meile, C., Shen, C., 2013. Quantification of extracellular carbonic anhydrase activity in two marine diatoms and investigation of its role. Plant Physiol. 162, 1142-1152.

Hoppe, C.J.M., Hassler, C.S., Payne, C.D., Tortell, P.D., Rost, B., Trimborn, S., 2013. Iron limitation modulates ocean acidification effects in Southern Ocean phytoplankton communities. PLoS One 8, e79890, http://dx.doi.org/10.1371/ journal.pone.0079890.

Hoppe, C.J., Holtz, L.M., Trimborn, S., Rost, B., 2015. Ocean acidification decreases the light-use efficiency in an Antarctic diatom under dynamic but not constant light. New Phytol. 207 (1), 159-171.

Hunter, K.A., Boyd, P.W., 2007. Iron-binding ligands and their role in the ocean biogeochemistry of iron. Environ. Chem. 4, 221-232.

Hutchins, D.A., DiTullio, G.R., Burland, K.W., 1993. Iron and regenerated production: evidence for biological iron recycling in two marine environments. Limnol. Oceanogr. 38, 1242-1255.

Hutchins, D.A., Witter, A.E., Butler, A., Luther, G.W., 1999. Competition among marine phytoplankton for different chelated iron species. Nature 400, 858-861.

IPCC: Climate Change, 2014. Synthesis Report. Contribution of Working Groups I, II and III to the Fifth Assessment Report of the Intergovernmental Panel on Climate Change. In: Core Writing Team, Pachauri, R.K., Meyer, L.A. (Eds.). IPCC, Geneva, Switzerland, p. 151.

Ishikawa, A, Wright, S.W. van den Enden, R. Davidson, A.T., Marchant, HJ. 2002. Abundance, size structure and community composition of phytoplankton in the Southern Ocean in the austral summer 1999/2000. Polar Biosci. 15, 11-26.

Janech, M.G., Krell, A., Mock, T., Kang, J.S., Raymond, J.A., 2006. Ice-binding proteins from sea ice diatoms (Bacillariophyceae). J. Phycol. 42, 410-416. 
Ji, R., Edwards, M., Mackas, D.L., Runge, J.A., Thomas, A.C., 2010. Marine plankton phenology and life history in a changing climate: current research and future directions. J. Plankton Res. 32, 1355-1368.

Kang, S.H., Fryxell, G.A., 1992. Fragilariopsis cylindrus (Grunow) Krieger: the most abundant diatom in water column assemblages of Antarctic marginal ice-edge zones. Polar Biol. 12, 609-627.

Kang, S.H., Fryxell, G.A., 1993. Phytoplankton in the Weddell Sea, Antarctica: composition, abundance and distribution in water-column assemblages of the marginal ice-edge zone during austral autumn. Mar. Biol. 116, 335-348.

Kang, S.H., Kang, J.S., Lee, S., Chung, K.H., Kim, D., Park, M.G., 2001. Antarctic phytoplankton assemblages in the marginal ice zone of the northwestern Weddell Sea. J. Plankton Res. 23, 333-352.

Kattner, G., Thomas, D.N., Haas, C., Kennedy, H., Dieckmann, G.S., 2004. Surface ice and gap layers in Antarctic sea ice: highly productive habitats. Mar. Ecol. Prog. Ser. 277, 1-12

Kawaguchi, S., Ichii, T., Haganobu, M., 1999. Green krill, the indicator of micro-and nano-sized phytoplankton availability to krill. Polar Biol. 22, 133-136.

Klausmeier, C.A., Litchman, E., Daufresne, T., Levin, S.A., 2008. Phytoplankton stoichiometry. Ecol. Res. 23, 479-485.

Kopczynska, E.E., Savoye, N., Dehairs, F., Cardinal, D., Elskens, M., 2007. Spring phytoplankton assemblages in the Southern Ocean between Australia and Antarctica. Polar Biol. 31, 77-88.

Kranz, S.A., Young, J.N., Hopkinson, B.M., Goldman, J.A.L., Tortell, P.D., Morel, F.M.M., 2015. Low temperature reduces the energetic requirement for the $\mathrm{CO} 2$ concentrating mechanism in diatoms. New Phytol. 205, 192-201.

Kropuenske, L., Mills, M., van Dijken, G., Bialey, S., Robinson, D., Welschmeyer, N., Arrigo, K., 2009. Photophysiology in two major Southern Ocean phytoplankton taxa:photoprotection in Phaeocystis antarctica and Fragilariopsis cylindrus. Limnol. Oceanogr. 54, 1176-1196.

Kropuenske, L.R., Mills, M.M., Van Dijken, G.L., Alderkamp, A.-C., Mine Berg, G., Robinson, D.H., et al., 2010. Strategies and rates of photoacclimation in two major Southern Ocean phytoplankton taxa: Phaeocystis antarctica (Haptophyta) and Fragilariopsis cylindrus (Bacillariophyceae). J. Phycol., 1138-1151, http://dx.doi.org/10.1111/j.1529-8817.2010.00922.x.

Kutska, A.B., Shaked, Y., Milligan, A.J., King, D.W., Morel, F.M.M., 2005. Extracellular production of superoxide by marine diatoms: contrasting effects on iron redox chemistry and bioavailability. Limnol. Oceanogr. 50, 1172-1180.

Lannuzel, D., Schoemann, V., De Jong, J., Tison, J.L., Chou, L., 2007. Distribution and biogeochemical behaviour of iron in the East Antarctic sea ice. Mar. Chem. 106, $18-32$

Lannuzel, D., Schoemann, V., de Jong, J., Chou, L., Delille, B., Becquevort, S., Tison, J.-L., 2008. Iron study during a time series in the western Weddell pack ice. Mar. Chem. 108, 85-95.

Lavaud, J., Strzepek, R., Kroth, P.G., 2007. Photoprotection capacity differs among diatoms: possible consequences on the spatial distribution of diatoms related to fluctuations in the underwater light climate. Limnol. Oceanogr. 52, $1188-1194$

Lee, S.H., Whitledge, T.E., Kang, S.H., 2008. Carbon uptake rates of sea ice algae and phytoplankton under different light intensities in a landfast sea ice zone. Barrow Alaska Arctic 61, 281-291.

Legendre, L., Ackerly, S.F., Dieckmann, G.S., Gulliksen, B., Horner, R., Hoshiai, T., et al., 1992. Ecology of sea ice biota: 2. Global significance. Polar Biol. 12 , 429-444.

Levitus, S., Antonov, J., Boyer, T., 2005. Warming of the world ocean, 1955-2003. Geophys. Res. Lett. 32, L02604.

Lewandowska, A.M., Boyce, D.G., Hofmann, M., Matthiessen, B., Sommer, U., Worm, B., 2014. Effects of sea surface warming on maine plankton. Ecol. Lett., http:// dx.doi.org/10.1111/ele.12265.

Liu, X., Millero, F.J., 1999. The solubility of iron hydroxide in sodium chloride solutions, Geochim. Cismochim. Acta 63, 3487-3497.

Lizotte, M.P., Sullivan, C.W., 1991. Rates of photoadaptation in sea ice diatoms from McMurdo Sound, Antarctica. J. Phycol. 27, 367-373.

Lizotte, M.P., Sullivan, C.W., 1992. Photosynthetic capacity in microalgae associated with Antarctic pack ice. Polar Biol. 12, 497-502.

Lizotte, M.P., 2001. The contributions of sea ice algae to antarctic marine primary production. Am. Zool. 41, 57-73.

Lovenduski, N.S., Gruber, N., 2005. Impact of the southern annular mode on southern ocean circulation and biology. Geophys. Res. Lett. 32, L11603.

Maldonado, M.T., Price, N.M., 1999. Utilization of iron bound to strong organic ligands by plankton communities in the subarctic Pacific Ocean. Deep Sea Res. Part II 46, 2447-2473.

Maldonado, M.T., Hughes, M.P., Rue, E.L., Wells, M.L., 2002. The effect of Fe and Cu on growth and domoic acid production by Pseudo-nitzschia multiseries and Pseudo-nitzschia australis. Limnol. Oceanogr. 47, 515-526.

Maldonado, M.T., Strzepek, R.F., Sander, S., Boyd, P.W., 2005. Acquisition of iron bound to strong organic complexes, with different Fe binding groups and photochemical reactivities, by plankton communities in Fe-limited subantarctic waters. Global Biogeochem. Cycles 19 (4), s1

Mangoni, O., Saggiomo, M., Modigh, M., Catalano, G., Zingone, A., Saggiomo, V., 2009. The role of platelet ice microalgae in seeding phytoplankton blooms in Terra Nova Bay (Ross Sea, Antarctica): a mesocosm experiment. Polar Biol. 32 311-323.

Marchant, H.J., Davidson, A.T., Wright, S.W., 2001. Antarctic marine microorganisms and climate change: impacts and feedbacks. Ocean Polar Res. 23, 401-410
Marchetti, A., Parker, M., Moccia, L., Lin, E., Arrieta, A., Ribalet, F., et al., 2009. Ferritin is used for iron storage in bloom-forming marine pennate diatoms. Nature 457, 467-470.

Marinov, I., Doney, S.C., Lima, I.D., 2010. Response of ocean phytoplankton community structure to climate change over the 21st century: partitioning the effects of nutrients, temperature and light. Biogeosci. Discuss. 7, 4565-4606.

Marshall, G.J., 2003. Trends in Southern Ocean annular mode from observations and reanalyses. J. Clim. 16, 4134-4143.

Martin, J.H., 1990. Glacial-interglacial $\mathrm{CO}_{2}$ change: the iron hypothesis. Paleoceanography 5, 1-13.

Massom, R.A., Stammerjohn, S.E., 2010. Antarctic sea ice change and variability-physical and ecological implications. Polar Sci. 4, 149-186.

McLeod, D.J., Hallegraeff, G.M., Hosie, G.W., Richardson, A.J., 2012. Climate-driven range expansion of the red-tide dinoflagellate Noctiluca scintillans into the Southern Ocean. J. Plankton Res. 34, 332-337.

McQuoid, M.R., Hobson, L.A., 1995. Importance of resting stages in diatom seasona succession. J. Phycol. 31, 44-50.

Meiners, K.M., Papadimitriou, S., Thomas, D.N., Norman, L., Dieckmann, G.S., 2009 Biogeochemical conditions and ice algal photosynthetic parameters in Weddell Sea ice during early spring. Polar Biol. 32, 1055-1065.

Miller, C.B., Frost, B.W., Wheeler, P.A., Landry, M.R., Welschmeyer, N., Powell, T.M., 1991. Ecological dynamics in the subarctic Pacific, a possibly iron-limited ecosystem. Limnol. Oceanogr. 36, 1600-1615.

Millero, F.J., 2009. Effect of Ocean acidification on the Speciation of Metals in Seawater. Oceanography 22, 72-85.

Milligan, A.J., Harrison, P.J., 2000. Effects of non-steady-state iron limitation on nitrogen assimilatory enzymes in the diatom Thalassiosira weissflogii (Bacillariophyceae). J. Phycol. 36, 78-86.

Mills, M.M., Kropuenske, L.R., Van Dijken, G.L., Alderkamp, A.-C., Berg, G.M., Robinson, D.H., et al., 2010. Photophysiology in two Southern Ocean phytoplankton taxa: photosynthesis of Phaeocystis antarctica (Prymnesiophyceae) and Fragilariopsis cylindrus (Bacillariophyceae) under simulated mixed-layer irradiance. J. Phycol. 46, 1114-1127.

Mills, M.M., Alderkamp, A.C., Thuroczy, C.E., van Dijken, G.L., Laan, P., de Baar, H.J.W., Arrigo, K.R., 2012. Phytoplankton biomass and pigment responses to $\mathrm{Fe}$ amendments in the Pine Island and Amundsen polynyas. Deep Sea Res. I 76, $61-76$.

Mioni, C.E., Handy, S.M., Ellwood, M.J., Twiss, M.R., McKay, R.M., Boyd, P.W., Wilhelm, S.W., 2005. Tracking changes in bioavailable Fe within high-nitrate low-chlorophyll-chlorophyll oceanic waters: a first estimate using a heterotrophic bacterial bioreporter. Global Biogeochem. Cycles 19 (4).

Mitchell, C., Beardall, J., 1996. Inorganic carbon uptake by an Antarctic sea-ice diatom, Nitzschia frigida. Polar Biol. 16, 95-99.

Mock, T., Hoch, N., 2005. Long-term temperature acclimation of photosynthesis in steady-state cultures of the polar diatom Fragilariopsis cylindrus. Photosynth. Res, 85, 307-317.

Mock, T., Kroon, B.M.A., 2002. Photosynthetic energy conversion under extreme conditions-I: important role of lipids as structural modulators and energy sink under N-limited growth in Antarctic sea ice diatoms. Phytochemistry 61, 41-51.

Moisan, T., Mitchell, B., 1999. Photophysiological acclimation of Phaeocystis antarctica Karsten under light limitation. Limnol. Oceanogr. 44, 247-258.

Moisan, T., Olaizola, M., Mitchell, B., 1998. Xanthophyll cycling in Phaeocystis antarctica: changes in cellular fluorescence. Mar. Ecol. Prog. Ser. 169, 113-121.

Moisan, J.R., Moisan, T.A., Abbott, M.R., 2002. Modelling the effect of temperature on the maximum growth rates of phytoplankton populations. Ecol. Modell. 153, 197-215.

Moline, M.A., Prézelin, B.B., 1996. Long-term monitoring and analysis of physical factors regulating variability in coastal Antarctic phytoplankton biomass, in situ productivity and taxonomic composition over sub-seasonal and interannual time scales. Mar. Ecol. Prog. Ser. 145, 143-160.

Moline, M.A., Claustre, H., Frazer, T.K., Schofield, O., Vernet, M., 2004. Alteration of the food web along the Antarctic Peninsula in response to a regional warming trend. Glob Change Biol. 10, 1973-1980.

Moore, J.K., Abbott, M.R., 2000. Phytoplankton chlorophyll distributions and primary production in the Southern Ocean. J. Geophys. Res. 105 (28), 709-722.

Moore, J.K., Braucher, O., 2008. Sedimentary and mineral dust sources of dissolved iron to the world ocean. Biogeosciences 5, 631-656.

Moore, C.M., Suggett, D.J., Hickman, A.E., Kim, Y., Tweddle, J.F., Sharples, J., Geider, R., Holligan, P.M., 2006. Phytoplankton photoacclimation and photoadaptation in response to environmental gradients in a shelf sea. Limnol. Oceanogr. 51, 936-949

Moore, C.M., Mills, M.M., Arrigo, K.R., Berman-Frank, I., Bopp, L., Boyd, P.W., et al., 2013. Processes and patterns of oceanic nutrient limitation. Nat. Geosci. 6, 701-710.

Morel, F.M.M., Price, N.M., 2003. The biogeochemical cycles of trace metals in the oceans. Science 300, 944-947.

Morel, F.M.M., Rueter, J., Price, N., 1991. Iron nutrition of phytoplankton and its possible importance in the ecology of ocean regions with high nutrient and low biomass. Oceanography 4, 56-61.

Morgan-Kiss, R.M., Priscu, J.C., Pocock, T., Gudynaite-Savitch, L., Huner, N.P.A., 2006. Adaptation and acclimation of photosynthetic microorganisms to permanently cold environments. Microbiol. Mol. Biol. Rev. 70, 222-252.

Nelson, D.M., Smith, W.O., 1991. Sverdrup revisited: critical depths, maximum chlorophyll levels and the control of Southern Ocean primary productivity by irradiance-mixing regime. Limnol. Oceanogr. 36, 1650-1661. 
Neven, I.A., Stefels, J., van Heuven, S.M.A., de Baar, H.J.W., 2011. Elzenga JTM. High plasticity in inorganic carbon uptake by Southern Ocean phytoplankton in response to ambient CO2. Deep Sea Res. II: Top. Stud. Oceanogr. 58, 2636-2646.

Norman, L., Worms, I.A.M., Angles, E., Bowie, A.R., Mancuso Nichols, A., Pham, A.N., et al., 2015. The role of bacterial and algal exopolymeric substances in iron chemistry. Mar. Chem. 173, 148-161.

Ogawa, H., Amagai, Y., Koike, I., Kaiser, K., Benner, R., 2001. Production of refractory dissolved organic matter by bacteria. Science 292, 917-920.

Peeken, I., 1997. Photosynthetic pigment fingerprints as indicators of phytoplankton biomass and development in different water masses of the Southern Ocean during austral spring. Deep Sea Res. I 44, 261-282.

Petrou, K., Ralph, P.J., 2011. Photosynthesis and net primary productivity in three Antarctic diatoms: possible significance for their distribution in the Antarctic marine ecosystem. Mar. Ecol. Prog. Ser. 437, 27-40.

Petrou, K., Hill, R., Brown, C.M., Campbell, D.A., Doblin, M.A., Ralph, P.J., 2010. Rapid photoprotection in sea-ice diatoms from the East Antarctic pack ice. Limnol. Oceanogr. 53, 1400-1407.

Petrou, K., Doblin, M.A., Ralph, P.J., 2011a. Heterogeneity in the photoprotective capacity of three Antarctic diatoms during short-term changes in salinity and temperature. Mar. Biol. 158, 1029-1041.

Petrou, K., Hassler, C.S., Doblin, M.A., Shelly, K., Schoemann, V., van den Enden, R., et al., 2011b. Iron-limitation and high light stress on phytoplankton populations from the Australian Sub-Antarctic Zone (SAZ). Deep Sea Res. Part II: Top. Stud. Oceanogr. 58, 2200-2211.

Petrou, K., Hill, R., Doblin, M.A., McMinn, A., Johnson, R., Wright, S.W., Ralph, P.J., 2011c. Photoprotection of sea ice microalgal communities from the East Antarctic pack ice. J. Phycol. 47, 77-86.

Petrou, K., Kranz, S.A., Doblin, M.A., Ralph, P.J., 2012. Photophysiological responses of Fragilariopsis cylindrus (Bacillariophyceae) to nitrogen depletion at two temperatures. J. Phycol. 48, 127-136.

Petrou, K., Trimborn, S., Rost, B., Ralph, P.J., Hassler, C.S., 2014. The impact of iron limitation on the physiology of the Antarctic diatom Chaetoceros simplex. Mar. Biol. 161, 925-937

Polovina, J.J., Howell, E.A., Abecassis, M., 2008. Ocean's least productive waters are expanding. Geophys. Res. Lett. 35 (3), L03618.

Poorvin, L., Rinta-Kanto, J.M. Hutchins, D.A., Wilhelm, S.W., 2004. Viral release of iron and its bioavailability to marine plankton. Limnol. Oceanogr. 49, $1734-1741$.

Raven, J.A., Evans, M.C.W., Korb, Korb, R.E., 1999. The role of trace metals in photosynthetic electron transport in O-2-evolving organisms. Photosynth. Res. $60(2-3), 111-149$.

Raymond, J.A., Knight, C.A., 2003. Ice binding, recrystallization inhibition, and cryoprotective properties of ice-active substances associated with Antarctic sea ice diatoms. Cryobiology 46, 174-181.

Reinfelder, J.R., 2011. Carbon concentrating mechanisms in eukaryotic marine phytoplankton. Annu. Rev. Mar. Sci. 3, 291-315.

Riebesell, U., Wolf-Gladrow, D.A., Smetacek, V., 1991. Carbon dioxide limitation of marine phytoplankton growth rates. Nature 361, 249-251.

Rintoul, S.R., Bullister, J.L., 1999. A late winter hydrographic section from Tasmania to Antarctica. Deep Sea Res. 46, 1417-1454.

Roberts, K., Granum, E., Leegood, R.C., Raven, J.A., 2007. Carbon acquisition by diatoms. Photosynth. Res. 93, 79-88.

Robinson, D.H., Kolber, Z., Sullivan, C.W., 1997. Photophysiology and photoacclimation in surface sea ice algae from McMurdo Sound, Antarctica. Mar. Ecol. Prog. Ser. 147, 243-256.

Rose, J.M., Caron, D.A., 2007. Does low temperature constrain the growth rates of heterotrophic protists? Evidence and implications for algal blooms in cold waters. Limnol. Oceanogr. 52, 886-895.

Rose, J.M., Feng, Y., DiTullio, G.R., Dunbar, R.B., Hare, C.E., Lee, P.A., et al., 2009. Synergistic effects of iron and temperature on Antarctic phytoplankton and microzooplankton assemblages. Biogeosciences 6, 3131-3147.

Rost, B., Riebesell, U., Sültemeyer, D., 2006. Carbon acquisition of marine phytoplankton: effect of photoperiod length. Limnol. Oceanogr. 51, 12-20.

Rost, B., Zondervan, I., Wolf-Gladrow, D., 2008. Sensitivity of phytoplankton to future changes in ocean carbonate chemistry: current knowledge, contradictions and research directions. Mar. Ecol. Prog. Ser. 373, 227-237.

Ruban, A., Lavaud, J., Rousseau, B., Guglielmi, G., Horton, P., Etienne, A.-L., 2004. The super-excess energy dissipation in diatom algae: comparative analysis with higher plants. Photosynth. Res. 82, 165-175.

Sabine, C.L., Feely, R.A., Gruber, N., Key, R.M., Lee, K., Bullister, J.L., et al., 2004. The oceanic sink for anthropogenic $\mathrm{CO}_{2}$. Science 305, 367-371.

Sackett, O., Petrou, K., Reedy, B., De Grazia, A., Hill, R., Doblin, M., Beardall, J., Ralph, P.J., Heraud, P., 2013. Phenotypic plasticity of southern ocean diatoms: key to success in the sea ice habitat? PLoS One, http://dx.doi.org/10.1371/journal. pone.0081185.

Sackett, O., Armand, L., Beardall, J., Hill, R., Doblin, M., Connelly, C., et al., 2014. Taxon-specific responses of Southern Ocean diatoms to Fe enrichment revealed by synchrotron radiation FTIR microspectroscopy. Biogeosciences 11 5795-5808.

Sackett, O., Petrou, K., Reedy, B., Hill, R., Doblin, M., Beardall, J., Ralph, P.J., Heraud, P., 2015. Snapshot prediction of carbon productivity, carbon and protein content in a Southern Ocean diatom using FTIR spectroscopy. ISME J., http://dx doi.org/10.1038/ismej.2015.123.

Sage, R.F., 2002. Variation in the kcat of Rubisco in C3 and C4 plants and some implications for photosynthetic performance at high and low temperature. J. Exp. Bot. 53, 609-620.
Saito, M.A., Goepfert, T.J., 2008. Zinc-cobalt colimitation of Phaeocystis antarctica. Limnol. Oceanogr. 53, 266-275.

Sarthou, G., Timmermans, K., Blain, S., Treguer, P., 2005. Growth physiology and fate of diatoms in the ocean: a review. J. Sea Res. 53, 25-42.

Shaked, Y., Kustka, A.B., Morel, F.M.M., 2005. A general kinetic model for iron acquisition by eukaryotic phytoplankton. Limnol. Oceanogr. 50, 872-882.

Shi, D., Xu, Y., Hopkinson, B.M., Morel, F.M., 2010. Effect of ocean acidification on iron availability to marine phytoplankton. Science 327, 676-679.

Smetacek, V., Nicol, S., 2005. Polar ocean ecosystems in a changing world. Nature 437, 362-368,

Smetacek, V., Klaas, C., Strass, V.H., Assmy, P., Montresor, M., Cisewski, B., et al., 2012. Deep carbon export from a Southern Ocean iron-fertilized diatom bloom. Nature 487, 313-319.

Smith, W.O., Comiso, J., 2008. Influence of sea ice on primary production in the Southern Ocean: a satellite perspective. J. Geophys. Res. Oceans, 93

Smith, W.O., Lancelot, C., 2004. Bottom-up versus top-down control in phytoplankton of the Southern Ocean. Ant. Sci. 16, 531-539.

Smith, W.O., Nelson, D.M., 1985. Phytoplankton bloom produced by a receding ice edge in the ross sea - spatial coherence with the density field. Science 227, 163-166.

Smith, W.O., Nelson, D.M., 1986. Importance of ice edge phytoplankton production in the Southern Ocean. BioSci 36, 251-257.

Smith, W.O., Dennett, M.R., Mathot, S., Caron, D.A., 2003. The temporal dynamics of the flagellated and colonial stages of Phaeocystis antarctica in the Ross Sea. Deep Sea Res. Part II 50, 605-617.

Sokolov, S., Rintoul, S.R., 2007. On the relationship between fronts of the Antarctic Circumpolar Current and surface chlorophyll concentrations in the Southern Ocean. J. Geophys. Res. 112, C07030.

Sommer, U., Lengfellner, K., 2008. Climate change and the timing, magnitude, and composition of the phytoplankton spring bloom. Global Change Biol. 14, 1199-1208.

Sommer, U., Lewandowska, A., 2011. Climate change and the phytoplankton spring bloom, warming and overwintering zooplankton have similar effects on phytoplankton. Global Change Biol. 17, 154-162.

Stocker, T.F., 2015. The silent services of the ocean. Science 350, 764-765.

Stoecker, D.K., Gustafson, D.E., Baier, C.T., Black, M.M.D., 2000. Primary production in the upper sea ice. Aquat. Microb. Ecol. 21, 275-287.

Strutton, P.G., Griffiths, F.B., Waters, R.L., Wright, S.W., Bindoff, N.L., 2000. Primary productivity off the coast of east Antarctica (890-150(E: January to march 1996. Deep Sea Res. II 47, 2327-2362.

Strzepek, R.F., Harrison, P.J., 2004. Photosynthetic architecture differs in coastal and oceanic diatoms. Nature 431, 689-692.

Strzepek, R., Maldonado, M., Higgins, J., Hall, J., Safi, K., Wilhelm, S., Boyd, P., 2005. Spinning the Ferrous Wheel: the importance of the microbial community in an iron budget during the FeCycle experiment. Global Biogeochem. Cycles 19 (4).

Strzepek, R.F., Hunter, K.A., Frew, R.D., Harrison, P.J., Boyd, P.W., 2012. Iron-light interactions differ in Southern Ocean phytoplankton. Limnol. Oceanogr. 57 $1182-1200$

Sugie, K., Yoshimura, T., 2013. Effects of pCO2 and iron on the elemental composition and cell geometry of the marine diatom Pseudo-nitzschia pseudodelicatissima (Bacillariophyceae). J. Phycol. 49, 475-488.

Sugie, K., Endo, H., Suzuki, K., Nishioka, J., Kiyosawa, H., Yoshimura, T., 2013. Synergistic effects of pCO2 and iron availability on nutrient consumption ratio of the Bering Sea phytoplankton community. Biogeosci. Discuss. 10, $4331-4365$.

Sunda, W.G., Huntsman, S.A., 1995. Iron uptake and growth limitation in oceanic and coastal phytoplankton. Mar. Chem. 50, 189-206.

Sunda, W.G., 1989. Trace metal interactions with marine phytoplankton. Biol. Oceanogr. 6, 411-442.

Swart, N., Fyfe, J., 2012. Observed and simulated changes in thye Southern Hemisphere surface westerly wind stress. Geophys. Res. Lett. 39, L16711

Takahashi, T., Sutherland, S.C., Sweeney, C., Poisson, A., Metzl, N., Tilbrook, B., et al., 2002. Global sea-air CO2 flux based on climatological surface ocean pCO2 and seasonal biological and temperature effects. Deep Sea Res. Part II 49, $1601-1622$

Thomas, D.N., Dieckmann, G.S., 2002. Antarctic sea Ice-a habitat for extremophiles. Science 295, 641-644.

Timmermans, K.R., Davey, M.S., van der Wagt, B., Snoek, J., Geider, R.J., Veldhuis, M.J.W., et al., 2001. Co-limitation by iron and light of Chaetoceros brevis, C. dichaeta and C. calcitrans (Bacillariophyceae). Mar. Ecol. Prog. Ser. 217, 287-297.

Timmermans, K.R., van der Wagt, B., de Baar, H.J., 2004. Growth rates, half-saturation constants, and silicate, nitrate, and phosphate depletion in relation to iron availability of four large, open-ocean diatoms from the Southern Ocean. Limnol. Oceanogr. 49, 2141-2151

Torstensson, A., Hedblom, M., Andersson, J., Andersson, M.X., Wulff, A., 2013. Synergism between elevated pCO2 and temperature on the Antarctic sea ice diatom Nitzschia lecointei. Biogeosciences 10, 6391-6401.

Torstensson, A., Hedblom, M., Mattsdotter Björk, M., Chierici, M., Wulff, A., 2015. Long-term acclimation to elevated pCO2 alters carbon metabolism and reduces growth in the Antarctic diatom Nitzschia lecointei. Proc. R. Soc. B 282, 20151513

Tortell, P.D., Payne, C.D., Li, Y., Trimborn, S., Rost, B., Smith, W.O., et al., 2008a. CO2 sensitivity of southern ocean phytoplankton. Geophys. Res. Lett. 35 (4). 
Tortell, P.D., Payne, C.D., Gueguen, C., Strzepek, R.F., Boyd, P.W., Rost, B., 2008b. Inorganic carbon uptake by Southern Ocean phytoplankton. Limnol. Oceanogr. 53, 1266-1278.

Tortell, P.D., Trimborn, S., Li, Y., Rost, B., Payne, C.D., 2010. Inorganic carbon uptake by Ross Sea phytoplankton across natural and experimental CO2 gradients. J. Phycol. 46, 433-443.

Tortell, P.D., Mills, M.M., Payne, C.D., Maldonado, M.T., Alderkamp, A.C., Arrigo, K.R., 2013. Inorganic $C$ utilization and $C$ isotope fractionation by pelagic and sea ice algal assemblages along the Antarctic continental shelf. Mar. Ecol. Prog. Ser. 483, 47-66.

Tortell, P.D., Asher, E.C., Ducklow, H.W., Goldman, J.A.L., Dacey, J.W.H., Grzymski, J.J., et al., 2014. Metabolic balance of coastal Antarctic waters revealed by autonomous pCO2 and Delta O2/Ar measurements. Geophys. Res. Lett. 41 6803-6810.

Trick, C.G., Wilhelm, S.W., 1995. Physiological changes in the coastal marine cyanobacterium Synechococcus sp. PCC 7002 exposed to low ferric ion levels. Mar. Chem. 50, 207-217.

Trimborn, S., Lundholm, N., Thoms, S., Richter, K.-U., Krock, B., Hansen, P. ., Rost, B., 2008. Inorganic carbon acquisition in potentially toxic and non-toxic diatoms: the effect of $\mathrm{pH}$-induced changes in the seawater carbonate chemistry. Physiol. Plant., http://dx.doi.org/10.1111/j.1399-3054.2007.01038.x.

Trimborn, S., Wolf-Gladrow, D., Richter, K.-U., Rost, B., 2009. The effect of pCO2 on the carbon acquisition and intracellular assimilation in four marine diatom species. J. Exp. Mar. Biol. Ecol. 376, 26-36.

Trimborn, S., Brenneis, T., Sweet, E., Rost, B., 2013. Sensitivity of Antarctic phytoplankton species to ocean acidification: growth, carbon acquisition and species interaction. Limnol. Oceanogr. 58, 997-1007.

Trimborn, S., Thoms, S., Petrou, K., Kranz, S.A., Rost, B., 2014. Photophysiological responses of Southern Ocean phytoplankton to changes in $\mathrm{CO} 2$ concentrations: short-term versus acclimation effects. J. Exp. Mar. Biol. Ecol. 451, 44-54.

Trimborn, S., Hoppe, C.J.M., Taylor, B., Bracher, A., Hassler, C.S., 2015. Physiological characteristics of phytoplankton communities of Western Antarctic Peninsula and Drake Passage waters. Deep Sea Res. I, http://dx.doi.org/10.1016/j.dsr. 2014.12.010.

Turner, J., Comiso, J.C., Marshall, G.J., Lachlan-Cope, T.A., Bracegirdle, T., Maksym, T., et al., 2009. Non-annular atmospheric circulation change induced by stratospheric ozone depletion and its role in the recent increase of Antarctic sea ice extent. Geophys. Res. Lett. 36, L08502.

Van Oijen, T., van Leeuwe, M.A., Wc, Gieskes W., de Baar, H.J.W., 2004. Effects of iron limitation on photosynthesis and carbohydrate metabolism in the
Antarctic diatom Chaetoceros brevis (Bacillariophyceae). Eur. J. Phycol. 39, $161-171$.

Wagner, H., Fanesi, A., Wilhelm, C., 2016. Freshwater phytoplankton response to environmental warming. J. Plant Physiol., this issue.

Westwood, K.J., Griffiths, F.B., Meiners, K.M., Williams, G.D., 2010. Primary productivity off the Antarctic coast from 30-80 E; BROKE-West survey, 2006 Deep Sea Res. II: Top. Stud. Oceanogr. 57, 794-814.

Whyte, J.N.C., 1987. Biochemical composition and energy content of six species of phytoplankton used in mariculture of bivalves. Aquaculture 60, 231-241.

Wilhelm, C., 1990. The biochemistry and physiology of light-harvesting processes in chlorophyll b- and chlorophyll c-containing algae. Plant Physiol. Biochem. 28, 293-306.

Williamson, C.E., Zagarese, H.E., 2003. UVR effects on aquatic ecosystems: a changing climate perspective. In: Helbling, E.W., Zagarese, H. (Eds.), UV Effects in Aquatic Organisms and Ecosystems. Comprehensive Series in Photochemistry and Photobiology, vol. 1. The Royal Society of Chemistry, Cambridge, UK, pp. 547-568.

Wohlers, J., Engel, A., Zöllner, E., Breithaupt, P., Jürgens, K., Hoppe, H.-G., Sommer, U., Riebesell, U., 2006. Changes in biogenic carbon flow in response to sea surface warming. Proc. Natl. Acad. Sci. 106, 7067-7072.

Wolf, C., Frickenhaus, S., Kilias, E.S., Peeken, I., Metfies, K., 2013. Regional variability in eukaryotic protist communities in the Amundsen Sea. Antarct. Sci. 25, 741-751.

Wright, S.W., van den Enden, R.L., 2000. Phytoplankton community structure and stocks in the East Antarctic marginal ice zone (BROKE survey, January? March 1996) determined by CHEMTAX analysis of HPLC pigment signatures. Deep Sea Res. II: Top. Stud. Oceanogr. 47, 2363-2400.

Wright, S.W., van den Enden, R.L., Pearce, I., Davidson, A.T., Scott, F.J., Westwood, K.J., 2010. Phytoplankton community structure and stocks in the Southern Ocean (30-80 E) determined by CHEMTAX analysis of HPLC pigment signatures. Deep Sea Res. II: Top. Stud. Oceanogr. 57, 758-778.

$\mathrm{Xu}, \mathrm{K}$. Fu, F.-X., Hutchins, D.A., 2014. Comparative responses of two dominant Antarctic phytoplankton taxa to interactions between ocean acidification, warming, irradiance, and iron availability. Limnol. Oceanogr. 59, 1919-1931.

Young, J.N., Goldman, J.A.L., Kranz, S.A., Tortell, P.D., Morel, F.M.M., 2015. Slow carboxylation of Rubisco constrains the rate of carbon fixation during Antarctic phytoplankton blooms. New Phytol. 205, 172-181.

van Leeuwe, M., Stefels, J., 2007. Photosynthetic responses in Phaeocystis antarctica towards varying light and iron conditions. Biogeochemistry 83, 61-70. 